\title{
Divergence of allosteric effects of rapacuronium on binding and function of muscarinic receptors
}

\author{
Jan Jakubík*1, Alena Randáková1 ${ }^{1}$ Esam E El-Fakahany² and \\ Vladimír Doležal ${ }^{1}$
}

\begin{abstract}
Address: ${ }^{1}$ Institute of Physiology, Academy of Sciences of the Czech Republic, Prague, Czech Republic and ${ }^{2}$ Division of Neuroscience Research in Psychiatry, University of Minnesota Medical School, Minneapolis, MN 55455, USA

Email: Jan Jakubík* - jakubik@biomed.cas.cz; Alena Randáková - randakova@biomed.cas.cz; Esam E El-Fakahany - elfak001@umn.edu; Vladimír Doležal - dolezal@biomed.cas.cz

* Corresponding author
\end{abstract}

Published: 28 December 2009

BMC Pharmacology 2009, 9:15 doi:10.1186/1471-2210-9-15
Received: 6 August 2009

Accepted: 28 December 2009

This article is available from: http://www.biomedcentral.com//47/-22/0/9//5

(c) 2009 Jakubík et al; licensee BioMed Central Ltd.

This is an Open Access article distributed under the terms of the Creative Commons Attribution License (http://creativecommons.org/licenses/by/2.0), which permits unrestricted use, distribution, and reproduction in any medium, provided the original work is properly cited.

\begin{abstract}
Background: Many neuromuscular blockers act as negative allosteric modulators of muscarinic acetylcholine receptors by decreasing affinity and potency of acetylcholine. The neuromuscular blocker rapacuronium has been shown to have facilitatory effects at muscarinic receptors leading to bronchospasm. We examined the influence of rapacuronium on acetylcholine (ACh) binding to and activation of individual subtypes of muscarinic receptors expressed in Chinese hamster ovary cells to determine its receptor selectivity.
\end{abstract}

Results: At equilibrium rapacuronium bound to all subtypes of muscarinic receptors with micromolar affinity (2.7-17 $\mu \mathrm{M})$ and displayed negative cooperativity with both high- and lowaffinity $\mathrm{ACh}$ binding states. Rapacuronium accelerated $\left[{ }^{3} \mathrm{H}\right] \mathrm{ACh}$ association with and dissociation from odd-numbered receptor subtypes. With respect to $\left.{ }^{35} \mathrm{~S}\right] \mathrm{GTP} \gamma \mathrm{S}$ binding rapacuronium alone behaved as an inverse agonist at all subtypes. Rapacuronium concentration-dependently decreased the potency of $A C h$-induced $\left[{ }^{35} \mathrm{~S}\right] \mathrm{GTP} \gamma \mathrm{S}$ binding at $\mathrm{M}_{2}$ and $\mathrm{M}_{4}$ receptors. In contrast, $0.1 \mu \mathrm{M}$ rapacuronium significantly increased $A C h$ potency at $M_{1}, M_{3}$, and $M_{5}$ receptors. Kinetic measurements at $M_{3}$ receptors showed acceleration of the rate of $A C h$-induced [ $\left.{ }^{35} \mathrm{~S}\right] \mathrm{GTP} \gamma \mathrm{S}$ binding by rapacuronium.

Conclusions: Our data demonstrate a novel dichotomy in rapacuronium effects at odd-numbered muscarinic receptors. Rapacuronium accelerates the rate of $\mathrm{ACh}$ binding but decreases its affinity under equilibrium conditions. This results in potentiation of receptor activation at low concentrations of rapacuronium $(I \mu M)$ but not at high concentrations $(10 \mu M)$. These observations highlight the relevance and necessity of performing physiological tests under nonequilibrium conditions in evaluating the functional effects of allosteric modulators at muscarinic receptors. They also provide molecular basis for potentiating $M_{3}$ receptor-mediated bronchoconstriction. 


\section{Background}

Five subtypes of muscarinic acetylcholine receptors that belong to class A of G-protein coupled receptors have been identified [1]. The primary response of stimulation of the $\mathrm{M}_{2}$ and $\mathrm{M}_{4}$ subtypes of muscarinic receptors is activation of the $\mathrm{G}_{\mathrm{i} / \mathrm{o}}$ class of $\mathrm{G}$-proteins resulting in inhibition of adenylyl cyclase, whereas stimulation of $M_{1}, M_{3}$, and $M_{5}$ receptors leads to activation of the $G_{q / 11}$ class of $G$ proteins and stimulation of phospholipase $\mathrm{C}[2]$. Muscarinic receptors mediate many diverse physiological functions that are selectively mediated by different receptor subtypes [3]. This is why discovery of selective ligands is of prime importance for clinical practice. However, due to the very conserved nature of the orthosteric binding site of muscarinic acetylcholine receptors the selectivity of orthosteric agonists is very poor [4]. Orthosteric antagonists that bind to less conserved amino acids located close to the orthosteric binding site display better selectivity than orthosteric agonists. Muscarinic allosteric ligands exhibit remarkable selectivity among receptor subtypes [5]. They interact mainly with the second and the third extracellular loops that are much less conserved than transmembrane segments creating the orthosteric binding site [6-10].

The extraordinary selectivity of allosteric modulators that is due to differences in both affinity and cooperativity [11] has attracted attention of pharmacologists in the past decade. Somewhat paradoxically, most of originally discovered and probably best studied allosteric compounds of muscarinic receptors are neuromuscular blockers [12-14]. By definition, these are competitive nicotinic acetylcholine receptor antagonists but many of them have high affinities and strong allosteric interactions, particularly at the $\mathrm{M}_{2}$ subtype of muscarinic receptors.

In clinical practice, different competitive (nondepolarizing) neuromuscular blockers are employed to induce muscle relaxation to facilitate intubation during surgery. The neuromuscular blocker rapacuronium was withdrawn from clinical use due to high incidence of bronchospasm resulting in death [15]. Parasympathetic innervation of airways transmits signal via postsynaptic $M_{3}$ receptors that mediate acetylcholine-induced contraction and $\mathrm{M}_{2}$ receptors that inhibit with high potency smooth muscle relaxation mediated by increase in cytoplasmic CAMP [16]. $\mathrm{M}_{2}$ receptors are also located at parasympathetic cholinergic nerve terminals innervating smooth muscle and their stimulation inhibits acetylcholine (ACh) release [17]. In functional experiments on the guinea pig trachea preparation it was demonstrated that rapacuronium preferentially antagonizes $\mathrm{M}_{2}$ over $\mathrm{M}_{3}$ muscarinic receptors [18]. In addition, involvement of allosteric potentiation of $\mathrm{ACh}$ binding to muscarinic $\mathrm{M}_{3}$ receptors in bronchospasm induced by rapacuronium was suggested, but not proven [19]. A very recent paper confirmed a unique behavior of rapacuronium compared to other skeletal muscle relaxants in vivo and demonstrated that rapacuronium potentiates bronchoconstriction evoked by both naturally released and exogenous acetylcholine, indicating an important role of postsynaptic $\mathrm{M}_{3}$ receptors [20].

Because we have been interested in investigations of positive cooperativity of allosteric ligands with ACh binding $[11,21]$ and allosteric agonists [22] these findings led us to analyze in detail the interactions of rapacuronium with acetylcholine binding and receptor activation of all subtypes of muscarinic receptors heterologously expressed in membranes of Chinese hamster ovary (CHO) cells. We demonstrate that rapacuronium binds to and exhibits negative cooperativity with ACh binding at all subtypes of muscarinic receptors. Surprisingly, low concentrations of rapacuronium potentiate ACh-induced signaling at the $M_{1}, M_{3}$, and $M_{5}$ receptor subtypes and accelerate ACh binding. This striking behavior is unparallel at other neuromuscular blockers.

\section{Results}

Saturation binding experiments (Figure 1; Table 1) with $68 \mathrm{pM}$ to $2 \mathrm{nM}\left[{ }^{3} \mathrm{H}\right] \mathrm{NMS}$ in cell membranes showed similar binding capacity ( 1 to 2 pmol of binding sites per $\mathrm{mg}$ of protein) and affinity (equilibrium dissociation constant $\left(\mathrm{K}_{\mathrm{D}}\right)$ ranging from $205 \mathrm{pM}$ at $\mathrm{M}_{4}$ to $320 \mathrm{pM}$ at $\mathrm{M}_{2}$ receptors) for all receptor subtypes (Figure. 1; Table 1). Significant depletion (up to $34 \%$ at $\mathrm{M}_{1}$ for $68 \mathrm{pM}$ $\left[{ }^{3} \mathrm{H}\right] \mathrm{NMS}$ ) occurred despite the use of $0.8 \mathrm{ml}$ incubation volume in the binding assays. Thus, free concentrations of $\left[{ }^{3} \mathrm{H}\right] \mathrm{NMS}$ were calculated and used in Eq. 1. Saturation binding experiments with $3.4 \mathrm{nM}$ to $100 \mathrm{nM}\left[{ }^{3} \mathrm{H}\right] \mathrm{ACh}$ showed similar high affinity binding among all subtypes with $\mathrm{K}_{\mathrm{D}}$ around $20 \mathrm{nM}$. Rapacuronium concentration dependently decreased affinity for $\left[{ }^{3} \mathrm{H}\right] \mathrm{NMS}$ and $\left[{ }^{3} \mathrm{H}\right] \mathrm{ACh}$ at all subtypes without change in maximum binding capacity $\left(\mathrm{B}_{\mathrm{MAX}}\right)$. Competition experiments of unlabeled ACh vs. $\left[{ }^{3} \mathrm{H}\right] \mathrm{NMS}$ displayed high and low binding sites for ACh at all subtypes with higher proportion of high affinity binding sites at even-numbered subtypes (Figure 2). Equilibrium dissociation constants $\left(\mathrm{K}_{\mathrm{I}}\right)$ of ACh high-affinity binding derived from competition experiments with $\left[{ }^{3} \mathrm{H}\right] \mathrm{NMS}\left(\mathrm{pK}_{\mathrm{D}}=7.32 \pm 0.06,7.59 \pm 0.03,7.79 \pm 0.05\right.$, $7.69 \pm 0.04,7.68 \pm 0.05$, mean \pm SE for $M_{1}$ to $M_{5}$ receptor) correspond to those measured in $\left[{ }^{3} \mathrm{H}\right] \mathrm{ACh}$ saturation experiments (Table 1). In the presence of $10 \mu \mathrm{M}$ GTP $\gamma \mathrm{S}$ to uncouple receptors and G-proteins ACh low affinity binding was similar at all five subtypes with equilibrium dissociation constant $\left(\mathrm{K}_{\mathrm{I}}\right)$ ranging from $25.5 \mu \mathrm{M}$ at $\mathrm{M}_{4}$ to 46.8 $\mu \mathrm{M}$ at $\mathrm{M}_{1}$. 

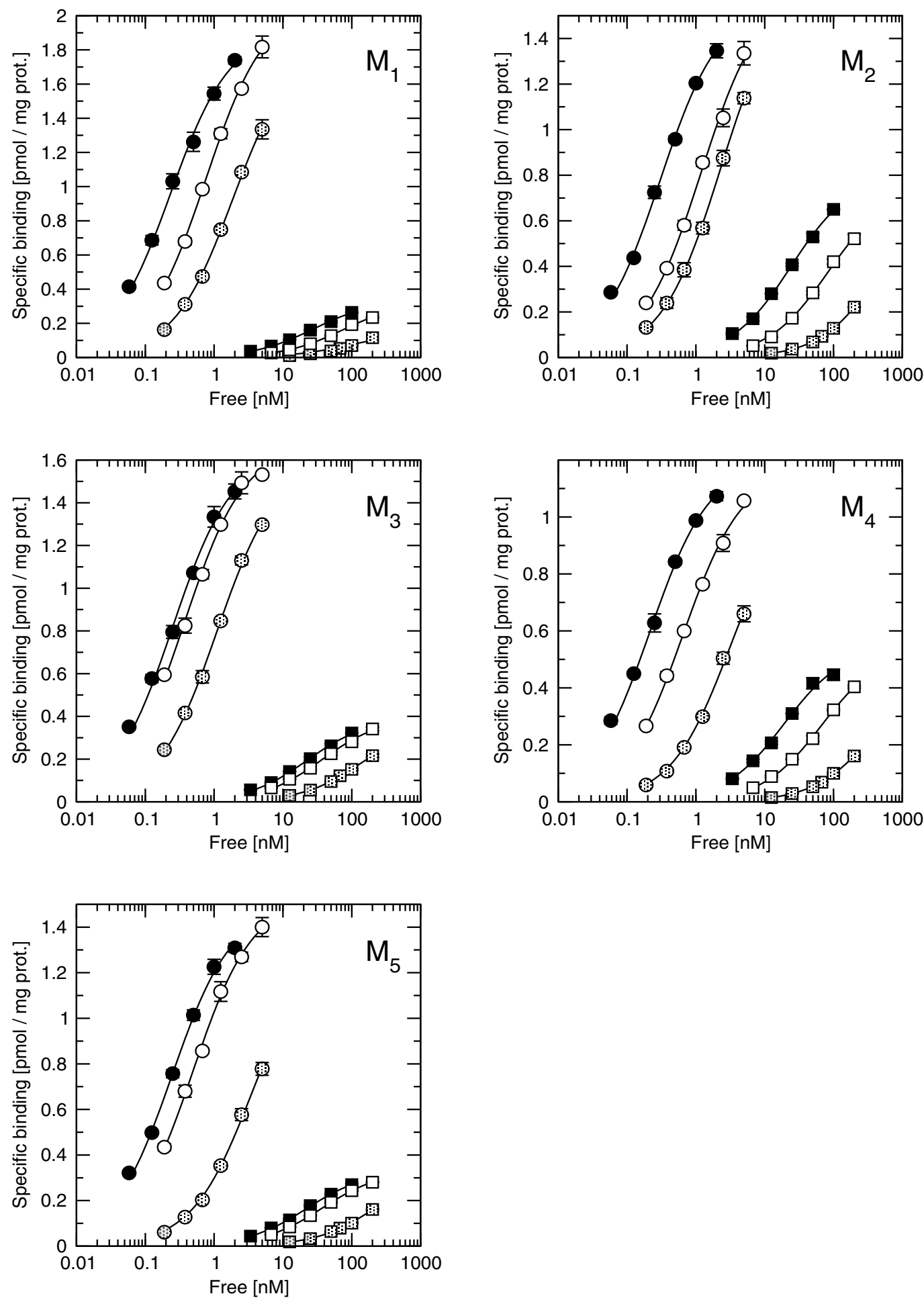

\section{Figure I}

Saturation binding of $\left[{ }^{3} \mathrm{H}\right] N M S$ and $\left[{ }^{3} \mathrm{H}\right]$ Ach. Specific binding of $\left[{ }^{3} \mathrm{H}\right] N M S$ (circles) and $\left[{ }^{3} \mathrm{H}\right] A C h$ (squares) to membranes from $\mathrm{CHO}$ cells expressing individual subtypes of muscarinic receptors is plotted against the concentration of free radioligand. Binding of radioligand in the absence (closed symbols) and presence of $10 \mu \mathrm{M}$ (open symbols) or $100 \mu \mathrm{M}$ (hatched symbols) rapacuronium, respectively. Data are means \pm SE from 3 independent experiments performed in quadruplicates. Curves are fits of Eq. I to data. Binding parameters are summarized in Table I. 

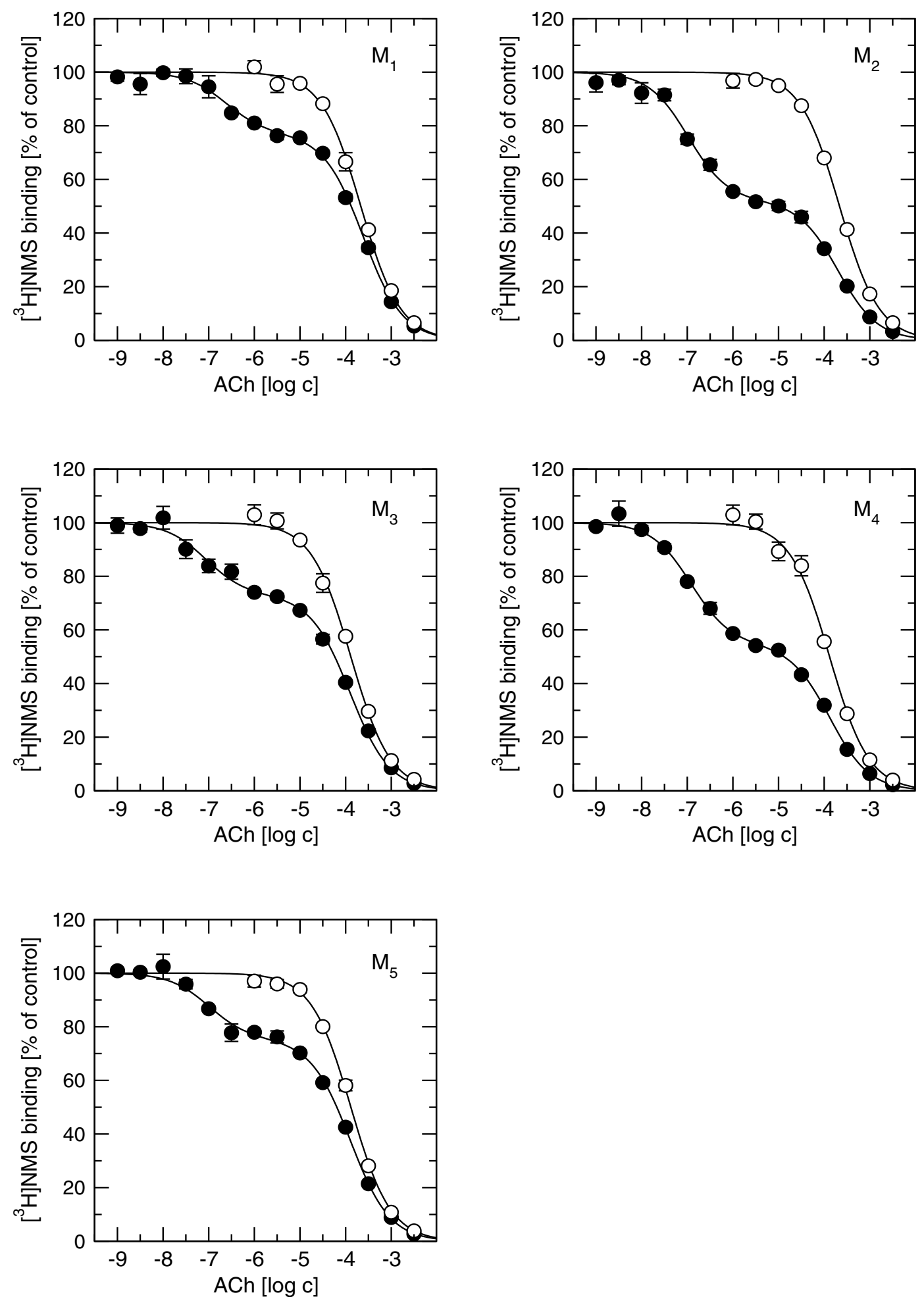

Figure 2

Effects of $10 \mu$ M GTP $\gamma$ S on ACh competition with $\left[{ }^{3} \mathbf{H}\right] \mathbf{N M S}$ binding. Binding of I $\mathrm{nM}\left[{ }^{3} \mathrm{H}\right] \mathrm{NMS}$ to the membranes from $\mathrm{CHO}$ cells expressing individual subtypes of muscarinic receptors in the absence (closed circles) or presence (open circles) of I $\mu$ M GTP $\gamma$ S is expressed as per cent of control binding and are plotted against concentration of ACh. Data are means \pm SE of 3 independent experiments performed in quadruplicates. Binding parameters are described in the Results. 
Table I: Effects of rapacuronium on $\left[{ }^{3} \mathrm{H}\right] \mathrm{NMS}$ and $\left[{ }^{3} \mathrm{H}\right] \mathrm{ACh}$ saturation binding

\begin{tabular}{|c|c|c|c|c|c|c|}
\hline & $\mathbf{p K}_{\mathrm{D}}$ & $B_{\text {MAX }}$ & $\mathrm{pK}_{\mathrm{D}}^{\prime}$ & $B_{\text {MAX }}$ & $\mathrm{pK}_{\mathrm{D}}^{\prime}$ & $B_{\text {MAX }}$ \\
\hline & \multicolumn{2}{|c|}{$\left[{ }^{3} \mathrm{H}\right] \mathrm{NMS}$} & \multicolumn{2}{|c|}{$+10 \mu \mathrm{M}$ rapacuronium } & \multicolumn{2}{|c|}{$+100 \mu \mathrm{M}$ rapacuronium } \\
\hline$M_{1}$ & $9.60 \pm 0.04$ & $1.98 \pm 0.20$ & $9.14 \pm 0.03 *$ & $2.03 \pm 0.15$ & $8.73 \pm 0.03 *$ & $1.85 \pm 0.17$ \\
\hline$M_{2}$ & $9.49 \pm 0.03$ & $1.56 \pm 0.16$ & $8.92 \pm 0.04^{*}$ & $1.62 \pm 0.14$ & $8.64 \pm 0.03 *$ & $1.66 \pm 0.14$ \\
\hline$M_{3}$ & $9.64 \pm 0.05$ & $1.64 \pm 0.17$ & $9.44 \pm 0.03 *$ & $1.67 \pm 0.14$ & $8.96 \pm 0.03 *$ & $1.59 \pm 0.16$ \\
\hline$M_{4}$ & $9.69 \pm 0.04$ & $1.19 \pm 0.14$ & $9.19 \pm 0.02 *$ & $1.17 \pm 0.13$ & $8.52 \pm 0.06 *$ & $1.06 \pm 0.10$ \\
\hline \multirow[t]{2}{*}{$M_{5}$} & $9.59 \pm 0.03$ & $1.49 \pm 0.16$ & $9.31 \pm 0.02 *$ & $1.53 \pm 0.15$ & $8.46 \pm 0.06^{*}$ & $1.33 \pm 0.13$ \\
\hline & \multicolumn{2}{|c|}{$\left[{ }^{3} \mathrm{H}\right] \mathrm{Ach}$} & \multicolumn{2}{|c|}{$+10 \mu \mathrm{M}$ rapacuronium } & \multicolumn{2}{|c|}{$+100 \mu \mathrm{M}$ rapacuronium } \\
\hline$M_{1}$ & $7.58 \pm 0.05$ & $0.33 \pm 0.05$ & $7.12 \pm 0.03 *$ & $0.33 \pm 0.05$ & $6.43 \pm 0.05^{*}$ & $0.32 \pm 0.05$ \\
\hline$M_{2}$ & $7.63 \pm 0.03$ & $0.80 \pm 0.08$ & $7.09 \pm 0.05^{*}$ & $0.74 \pm 0.07$ & $6.30 \pm 0.06^{*}$ & $0.77 \pm 0.08$ \\
\hline$M_{3}$ & $7.67 \pm 0.05$ & $0.39 \pm 0.05$ & $7.43 \pm 0.04 *$ & $0.40 \pm 0.04$ & $6.85 \pm 0.03^{*}$ & $0.37 \pm 0.05$ \\
\hline$M_{4}$ & $7.69 \pm 0.04$ & $0.55 \pm 0.04$ & $7.17 \pm 0.03 *$ & $0.54 \pm 0.05$ & $6.41 \pm 0.05^{*}$ & $0.47 \pm 0.04$ \\
\hline$M_{5}$ & $7.68 \pm 0.03$ & $0.33 \pm 0.06$ & $7.43 \pm 0.02 *$ & $0.33 \pm 0.03$ & $6.64 \pm 0.04 *$ & $0.34 \pm 0.06$ \\
\hline
\end{tabular}

Negative logarithms of equilibrium dissociation constants $\left(\mathrm{pK}_{\mathrm{D}}\right)$ and maximum binding capacities $\left(\mathrm{B}_{\mathrm{MAX}}\right.$ in $\mathrm{fmol} / \mu \mathrm{g}$ of protein) of radioligands were obtained from saturation experiments shown in Figure I by fitting Eq. I to the data. Values are means \pm SE of fits to 3 independent experiments performed in quadruplicates.

$* \mathrm{P}<0.05$; significantly different from control (radioligand alone) by ANOVA and Tukey-Kramer post-test.

Effects of $100 \mu \mathrm{M}$ rapacuronium on the rate of $\left(\left[{ }^{3} \mathrm{H}\right] \mathrm{NMS}\right)$ dissociation were measured in membranes from $\mathrm{CHO}$ cell expressing individual subtypes of muscarinic receptors after 60 min preincubation with $1 \mathrm{nM}\left[{ }^{3} \mathrm{H}\right] \mathrm{NMS}$. Dissociation was evoked by addition of $10 \mu \mathrm{M}$ unlabeled NMS. Rapacuronium slowed dissociation of $\left[{ }^{3} \mathrm{H}\right] \mathrm{NMS}$ from all subtypes of muscarinic ACh receptors (Figure 3, Table 2). This is an established hallmark of allosteric receptor modulation. It had the strongest effect at $\mathrm{M}_{2}$ receptors (7-fold decrease in rate of dissociation) and weakest effect at $\mathrm{M}_{3}$ and $M_{5}$ receptors (40\% decrease). While dissociation evoked by NMS was monophasic (Figure 3 closed symbols) it became biphasic in the presence of $100 \mu \mathrm{M}$ rapacuronium with the exception of the $\mathrm{M}_{5}$ subtype.

Table 2: Effects of rapacuronium on the rate of $\left[{ }^{3} \mathrm{H}\right] \mathrm{NMS}$ dissociation.

\begin{tabular}{ccccc}
\hline & Control & \multicolumn{3}{c}{$+100 \mu M$ rapacuronium } \\
& $\mathbf{k}_{\text {off }}\left[\mathbf{m i n}^{-1}\right]$ & $\mathbf{k}_{\text {off } 1}\left[\mathbf{m i n}^{-1}\right]$ & $\mathbf{f}_{\mathbf{2}}[\%]$ & $\mathbf{k}_{\text {off2 }}\left[\mathbf{m i n}^{-1}\right]$ \\
\hline$M_{1}$ & $0.063 \pm 0.004$ & $0.014 \pm 0.001 *$ & $14 \pm 3$ & $0.34 \pm 0.05$ \\
$M_{2}$ & $0.18 \pm 0.01$ & $0.026 \pm 0.002^{*}$ & $23 \pm 5$ & $0.76 \pm 0.11$ \\
$M_{3}$ & $0.048 \pm 0.003$ & $0.031 \pm 0.002^{*}$ & $20 \pm 4$ & $0.058 \pm 0.009$ \\
$M_{4}$ & $0.041 \pm 0.002$ & $0.017 \pm 0.001^{*}$ & $6.0 \pm 2.0$ & $0.75 \pm 0.11$ \\
$M_{5}$ & $0.013 \pm 0.001$ & $0.0078 \pm 0.0004^{*}$ & & \\
\hline
\end{tabular}

Observed rates of $\left[{ }^{3} \mathrm{H}\right] \mathrm{NMS}$ dissociation $\left(\mathrm{k}_{\text {off }}, \mathrm{k}_{\text {offl }}\right.$ and $\left.\mathrm{k}_{\text {off }}\right)$ and fraction of sites $\left(f_{2}\right)$ with faster dissociation $\left(k_{\text {off }}\right)$ from individual subtypes of muscarinic receptors were obtained by fitting Eq. $7 \mathrm{a}$ and $7 \mathrm{~b}$ to data in Figure 3. Results of better fit are shown. Values are means \pm SE of fits to 3 independent experiments performed in quadruplicates. $* \mathrm{P}<0.05$; significantly different from control $\left({ }^{3} \mathrm{H}\right] \mathrm{NMS}$ alone) by t-test
Displacement radioligand binding experiments with either $20 \mathrm{nM}\left[{ }^{3} \mathrm{H}\right] \mathrm{ACh}$ (Figure 4) or $1 \mathrm{nM}\left[{ }^{3} \mathrm{H}\right] \mathrm{NMS}$ (Figure 5, circles) and increasing concentrations of rapacuronium showed that rapacuronium binds equally well to all five muscarinic receptor subtypes. Equilibrium dissociation constants $\left(\mathrm{pK}_{\mathrm{A}}\right.$; Table 3 ) for rapacuronium derived from experiments with $\left[{ }^{3} \mathrm{H}\right] \mathrm{NMS}$ and $\left[{ }^{3} \mathrm{H}\right] \mathrm{ACh}$ were virtually the same with a rank order of affinity of $\mathrm{M}_{2}>\mathrm{M}_{4}>\mathrm{M}_{1}>\mathrm{M}_{5}>\mathrm{M}_{3}$ (range from 2.6-17.8 $\mu \mathrm{M}$ ). Rapacuronium displayed negative cooperativity with $\left[{ }^{3} \mathrm{H}\right] \mathrm{NMS}$ in binding to all subtypes, as evidenced by a maximal limit to its effects on the affinity of the radioligand that differed as a function of radioligand concentration. These effects were strongest at the $M_{5}$ subtype (35-fold decrease in affinity) and weakest at the $\mathrm{M}_{2}$ subtype (6.8-fold decrease in affinity; Figure 5, closed circles). While cooperativity of rapacuronium with high- $(p \alpha)$ and low-affinity $(p \beta)$ ACh binding was essentially the same at individual subtypes (Table 3, row-wise comparison) it was slightly different among subtypes (e.g. 16-fold decrease in ACh low-affinity binding at $\mathrm{M}_{3}$ receptors vs. 36-times decrease at $\mathrm{M}_{4}$ receptors; Table 3, column-wise comparison).

Rapacuronium alone concentration dependently lowered [35S]GTP $\gamma S$ binding to membranes (Figure 6, closed squares; Table 4) with a maximal effect of approximately $25 \%$ at odd-numbered subtypes and $15 \%$ at even-numbered subtypes, with similar half-effective concentrations $\left(\mathrm{EC}_{50}\right)$ ranging from $28 \mu \mathrm{M}$ at $\mathrm{M}_{2}$ receptors to $76 \mu \mathrm{M}$ at $\mathrm{M}_{3}$ receptors. While the $\mathrm{EC}_{50}$ values of rapacuronium in inhibiting $\left[{ }^{35} \mathrm{~S}\right] \mathrm{GTP} \gamma \mathrm{S}$ binding at individual subtypes correlated with affinities measured in binding experiments with $\left[{ }^{3} \mathrm{H}\right] \mathrm{ACh}\left(\mathrm{R}^{2}=0.76\right)$ they were lower $(4$ - to 12 -fold $)$ 

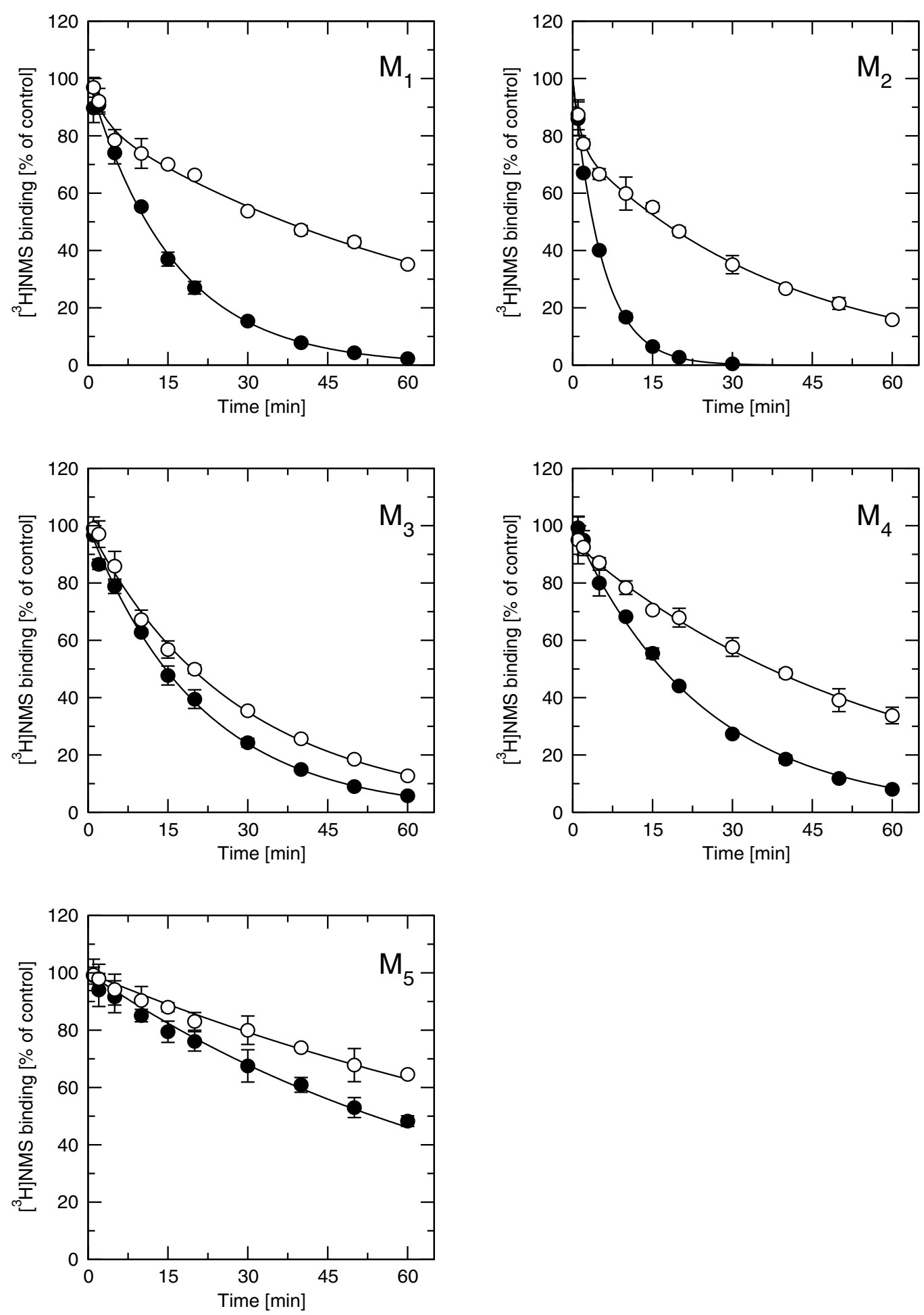

Figure 3

Effects of $100 \mu \mathrm{M}$ rapacuronium on dissociation of $\left[{ }^{3} \mathbf{H}\right] \mathbf{N M S}$ binding. Binding of $\left[{ }^{3} \mathrm{H}\right] \mathrm{NMS}$ to membranes from $\mathrm{CHO}$ cells expressing individual subtypes of muscarinic receptors at different times after the addition of $10 \mu \mathrm{M}$ NMS (closed circles) or a mixture of $10 \mu \mathrm{M} N \mathrm{MS}$ and $100 \mu \mathrm{M}$ rapacuronium (open circles). Specific binding is expressed as percent of binding at time 0 . Data are means \pm SE from 3 independent experiments performed in quadruplicates. Binding parameters are summarized in Table 2. 
Table 3: Binding parameters of NMS, $\mathrm{ACh}$ and rapacuronium to membranes from $\mathrm{CHO}$ cells expressing $M_{1}$ through $M_{5}$ receptor subtypes.

\begin{tabular}{|c|c|c|c|c|c|c|}
\hline & \multicolumn{2}{|c|}{$\left[{ }^{3} \mathrm{H}\right] N M S$} & \multicolumn{2}{|c|}{$\begin{array}{c}{\left[{ }^{3} \mathrm{H}\right] A c h} \\
\text { high affinity binding }\end{array}$} & \multicolumn{2}{|c|}{$\begin{array}{c}\text { Ach } \\
\text { low affinity binding }\end{array}$} \\
\hline & $\mathrm{pK}_{\mathrm{A}}$ & $\mathbf{p} \alpha$ & $\mathrm{pK}_{\mathrm{A}}$ & $\mathbf{p} \alpha$ & $\mathrm{pK}_{\mathrm{A}}$ & $\mathrm{p} \beta$ \\
\hline$M_{1}$ & $5.37 \pm 0.03$ & $-1.08 \pm 0.05$ & $5.37 \pm 0.04$ & $-1.30 \pm 0.07$ & $5.33 \pm 0.03$ & $-1.32 \pm 0.06$ \\
\hline$M_{2}$ & $5.59 \pm 0.03$ & $-0.83 \pm 0.07$ & $5.55 \pm 0.05$ & $-1.46 \pm 0.08$ & $5.56 \pm 0.04$ & $-1.52 \pm 0.06$ \\
\hline$M_{3}$ & $4.75 \pm 0.04$ & $-1.11 \pm 0.05$ & $4.80 \pm 0.04$ & $-1.26 \pm 0.05$ & $4.77 \pm 0.05$ & $-1.20 \pm 0.07$ \\
\hline$M_{4}$ & $5.42 \pm 0.04$ & $-1.40 \pm 0.04$ & $5.41 \pm 0.05$ & $-1.51 \pm 0.05$ & $5.49 \pm 0.04$ & $-1.56 \pm 0.07$ \\
\hline$M_{5}^{4}$ & $4.97 \pm 0.04$ & $-1.54 \pm 0.05$ & $4.92 \pm 0.03$ & $-1.34 \pm 0.07$ & $4.95 \pm 0.04$ & $-1.28 \pm 0.07$ \\
\hline
\end{tabular}

Negative logarithm of equilibrium dissociation constant of rapacuronium $\left(\mathrm{pK}_{\mathrm{A}}\right)$ and factor of cooperativity $(\alpha)$ between rapacuronium and radioligand $\left(\left[{ }^{3} \mathrm{H}\right] \mathrm{NMS}\right.$ or $\left[{ }^{3} \mathrm{H}\right] \mathrm{ACC}$, respectively) binding were obtained by fitting Eq. 3 to the data in Figures 4 and 5 . Negative logarithm of equilibrium dissociation constant of rapacuronium $\left(\mathrm{pK}_{\mathrm{A}}\right)$ and factors of cooperativity $(\beta)$ between rapacuronium and acetylcholine low affinity binding were obtained by fitting Eq. 4 to the data in Figure 5. Factors of cooperativity $\alpha$ and $\beta$ are expressed as negative logarithms so that negative values represent negative cooperativity. Values are means \pm SE of fits to 3 independent experiments performed in quadruplicates.

at all subtypes. We could not test the involvement of muscarinic receptors in the effects of rapacuronium on $\left[{ }^{35} \mathrm{~S}\right] \mathrm{GTP} \gamma \mathrm{S}$ binding using orthosteric antagonists, since 10 $\mu \mathrm{M} N \mathrm{NS}$ or $10 \mu \mathrm{M}$ atropine by themselves decreased [35S]GTP $\gamma$ S binding by more than $30 \%$ at all receptor subtypes. Inhibitory effects of rapacuronium were not addi-

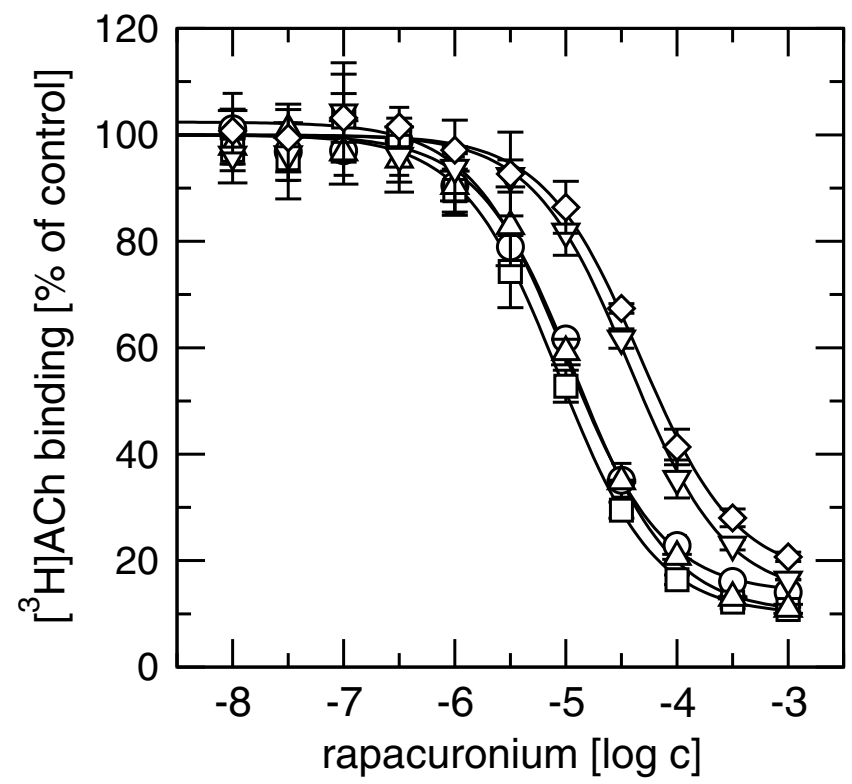

Figure 4

Effects of rapacuronium on high-affinity [ $\left.{ }^{3} \mathrm{H}\right] \mathrm{ACh}$ binding. Binding of $20 \mathrm{nM}\left[{ }^{3} \mathrm{H}\right] \mathrm{ACh}$ to membranes from $\mathrm{CHO}$ cells expressing individual subtypes of muscarinic receptors (circles, $M_{1}$; squares, $M_{2}$; diamonds, $M_{3}$; up-triangles, $M_{4}$; down-triangles, $M_{5}$ ) was determined in the presence of rapacuronium at the concentrations indicated on the $x$ axis and is expressed as percent of specific binding in the absence of rapacuronium. Data are means \pm SE from 3 independent experiments performed in quadruplicates. Curves are fits of Eq. 3 to data. Binding parameters are summarized in Table 3. tive to those of NMS or atropine (not shown). However, rapacuronium did not decrease $\left.{ }^{35} \mathrm{~S}\right] \mathrm{GTP} \gamma \mathrm{S}$ binding in membranes from nontransfected $\mathrm{CHO}$ cells (Figure 6, bottom row right).

As expected, ACh concentration-dependently stimulated [ ${ }^{35}$ S]GTP $\gamma$ S binding to membranes from cells expressing all individual subtypes of muscarinic receptors (Table 4 and Figure 6, closed circles). The maximal effect of ACh $\left(\mathrm{E}_{\mathrm{MAX}}\right)$ was about two-fold increase in basal binding at odd-numbered receptors and three-fold increase at evennumbered receptors with a rank order of efficacy of $\mathrm{M}_{2}>\mathrm{M}_{4}>\mathrm{M}_{1}>\mathrm{M}_{5}>\mathrm{M}_{3}$ (range from 3.12 to 1.99-fold increase). In control conditions $\mathrm{ACh}_{\mathrm{EC}_{50}}$ values were lower at even-numbered subtypes than at odd-numbered subtypes with a rank order of potency of $\mathrm{M}_{2}>\mathrm{M}_{4}>\mathrm{M}_{3}>\mathrm{M}_{5}>\mathrm{M}_{1}$ (range from 0.25 to $6.31 \mu \mathrm{M}$ ) (Table $5)$. While the $\mathrm{EC}_{50}$ of ACh-stimulated [ $\left.{ }^{35} \mathrm{~S}\right] \mathrm{GTP} \gamma \mathrm{S}$ binding was less than that of its low-affinity binding conformation by 178-times at $M_{2}$ and 23-times at $M_{4}$ receptors it was only 7.4-, 5.4-, and 4.7-times lower at $M_{1}, M_{3}$, and $M_{5}$ receptors, respectively. In comparison with its high-affinity binding, the $\mathrm{EC}_{50}$ of ACh-stimulated [ $\left.{ }^{35} \mathrm{~S}\right] \mathrm{GTP} \gamma \mathrm{S}$ binding was only 10-times higher at $\mathrm{M}_{2}$ and 55-times at $\mathrm{M}_{4}$ receptors but 130-260- and 300-times higher at $M_{1}, M_{5}$ and $\mathrm{M}_{3}$ receptors, respectively. $\mathrm{E}_{\mathrm{MAX}}$ was about two-fold increase in basal binding at odd-numbered receptors and three-fold increase at even-numbered receptors with a rank order of efficacy of $M_{2}>M_{4}>M_{1}>M_{5}>M_{3}$ (range from 3.12 to 1.99 -fold increase) (Table 5).

Measurements of ACh-stimulated [ ${ }^{35}$ S]GTP $\gamma \mathrm{S}$ binding in the presence of $0.1,1$ and $10 \mu \mathrm{M}$ rapacuronium showed differential effects of rapacuronium on receptor activation by an orthosteric agonist at individual receptor subtypes (Figure 6 open symbols). At even-numbered subtypes 1 $\mu \mathrm{M}$ and $10 \mu \mathrm{M}$ rapacuronium significantly increased $\mathrm{ACh}$ $\mathrm{EC}_{50}$, with lowering of $\mathrm{E}_{\mathrm{MAX}}$ at $10 \mu \mathrm{M}$ rapacuronium. These results are in line with the effects of rapacuronium 

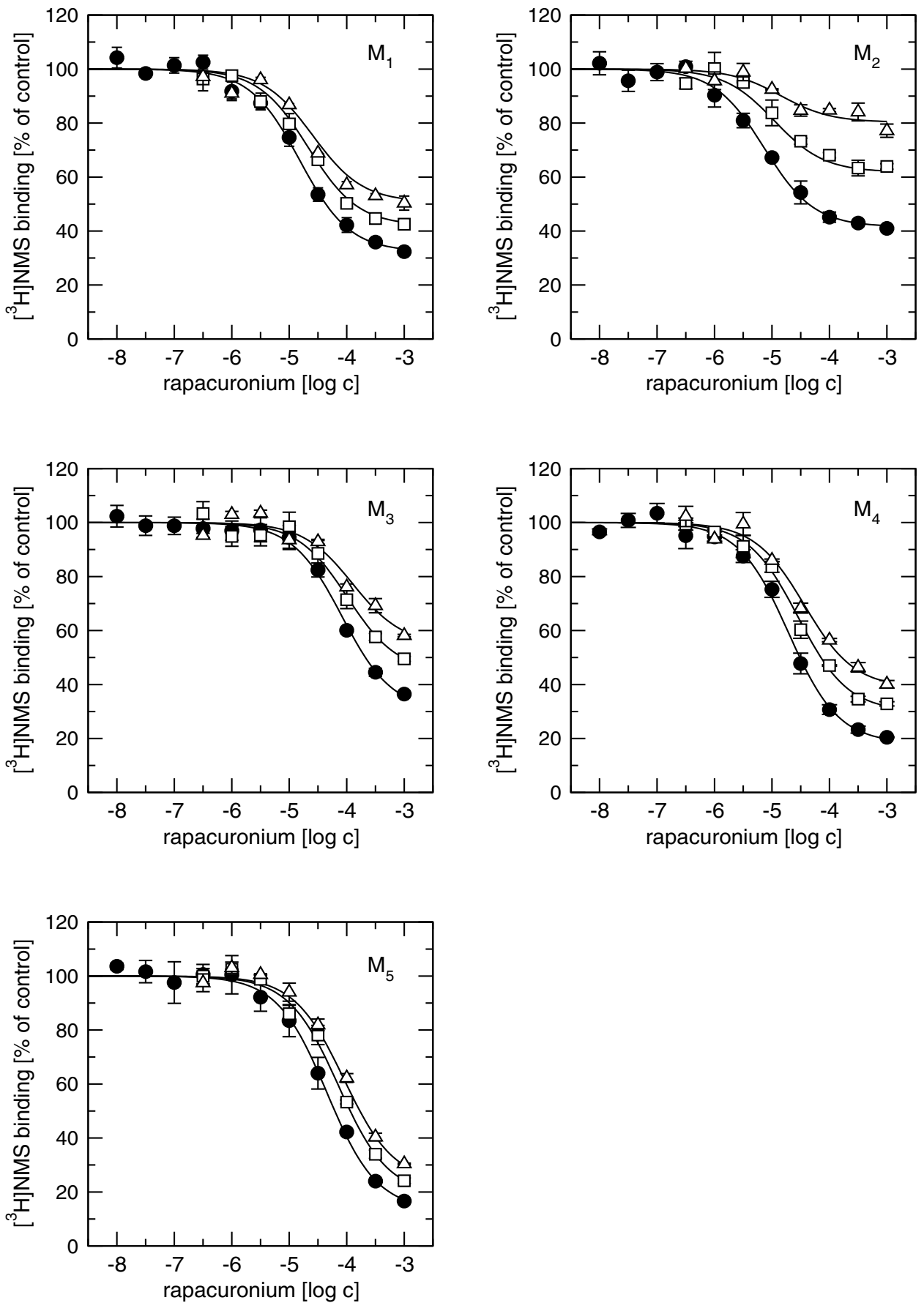

Figure 5

Effects of rapacuronium on low-affinity $\mathbf{A C h}$ binding and $\left[{ }^{3} \mathbf{H}\right] \mathbf{N M S}$ binding. Binding of I nM $\left[{ }^{3} \mathrm{H}\right] \mathrm{NMS}$ to membranes from $\mathrm{CHO}$ cells expressing individual subtypes of muscarinic receptors was measured in the presence of rapacuronium at the concentrations indicated on the $\mathrm{x}$-axis. Data are expressed as percent of specific binding in the absence of rapacuronium. Symbols represent binding of $\left[{ }^{3} \mathrm{H}\right] \mathrm{NMS}$ (circles), and $\left[{ }^{3} \mathrm{H}\right] \mathrm{NMS}$ in the presence of $10 \mu \mathrm{M} \mathrm{GTP} \gamma \mathrm{S}$ and $\mathrm{I} 00 \mu \mathrm{M}$ (squares) or $200 \mu \mathrm{M}$ (triangles) ACh. Binding of [ $\left.{ }^{3} \mathrm{H}\right] \mathrm{NMS}$ was decreased by $100 \mu \mathrm{M} \mathrm{ACh}$ to 7I, 64, 59, 60 and $56 \%$ and by $200 \mu \mathrm{M}$ ACh to 55, 47, 42,43 and $39 \%$ at $M_{1}$ to $M_{5}$ receptors, respectively. Bigger divergence of curves denotes stronger negative cooperativity between $\mathrm{ACh}$ and rapacuronium binding. Data are means \pm SE from 3 independent experiments performed in quadruplicates. Curves are fits of Eq. 3 (circles) and Eq. 4 (squares and triangles) to data prior to normalization. Binding parameters are summarized in Table 3. 
Table 4: Direct effects of rapacuronium on $\left[{ }^{35} \mathrm{~S}\right] \mathrm{GTP} \gamma \mathrm{S}$ binding

\begin{tabular}{cccccc}
\hline & $M_{1}$ & $M_{2}$ & $M_{3}$ & $M_{4}$ & $M_{5}$ \\
\hline$P E C_{50}$ & $4.30 \pm 0.04$ & $4.55 \pm 0.04$ & $4.12 \pm 0.03$ & $4.44 \pm 0.04$ & $4.21 \pm 0.04$ \\
$\mathrm{E}_{\mathrm{MAX}}$ & $0.76 \pm 0.08$ & $0.84 \pm 0.06$ & $0.75 \pm 0.07$ & $0.86 \pm 0.06$ & $0.75 \pm 0.07$ \\
\hline
\end{tabular}

Negative logarithms of half effective concentrations $\left(\mathrm{pEC}_{50}\right.$ ) and $\mathrm{E}_{\mathrm{MAX}}$ of rapacuronium on $\left[{ }^{35} \mathrm{~S}\right] \mathrm{GTP} \gamma \mathrm{S}$ binding were obtained by fitting Eq. 5 to the data from the measurements of $\left[{ }^{35} \mathrm{~S}\right] \mathrm{GTP} \gamma \mathrm{S}$ binding in the presence of rapacuronium in concentrations ranging from $10^{-8}$ to $10^{-3} \mathrm{M}$ normalized to the absence of rapacuronium (Figure 6, open squares). Values are means \pm SE of fits to 3 independent experiments performed in quadruplicates.

on ACh binding. In contrast, the effects of rapacuronium on activation of odd-numbered subtypes were more complex. At these subtypes rapacuronium had the strongest effect on activation of the $M_{3}$ subtype. At this subtype 0.1 and $1 \mu \mathrm{M}$ rapacuronium caused a significant 2 -fold decrease in $\mathrm{ACh}^{\mathrm{EC}_{50}}$ and approximately $60 \%$ and $35 \%$ increase in $\mathrm{E}_{\mathrm{MAX}}$, respectively. Rapacuronium at $10 \mu \mathrm{M}$ increased $\mathrm{ACh} \mathrm{EC}_{50}$ by about 3-fold without a significant change in $\mathrm{E}_{\mathrm{MAX}}$. Rapacuronium $(0.1-10 \mu \mathrm{M})$ had no effect on ACh efficacy at the $M_{1}$ and $M_{5}$ subtypes but decreased the $\mathrm{EC}_{50}$ of $\mathrm{ACh}$ in stimulating [35S]GTP $\gamma \mathrm{S}$ binding by 1.5- and 4-fold, respectively, at concentrations of 0.1 and $1 \mu \mathrm{M}$. However, this effect was not evident at $10 \mu \mathrm{M}$ rapacuronium (Figure 6 ).

Kinetics of [ $\left.{ }^{35} \mathrm{~S}\right] \mathrm{GTP} \gamma \mathrm{S}$ binding to membranes from $\mathrm{CHO}-$ $\mathrm{M}_{3}$ cells (where rapacuronium has the most pronounced effects) were measured after 5 min preincubation with 5 $\mu \mathrm{M}$ GDP and 60 min with $1 \mu \mathrm{M}$ rapacuronium followed by simultaneous addition of $\left[{ }^{35}\right.$ S]GTP $\gamma S$ and ACh, with or without rapacuronium (Figure 7). Under basal conditions ([ ${ }^{35}$ S]GTP $\gamma \mathrm{S}+$ buffer, Figure 7, closed circles) [ ${ }^{35}$ S]GTP $\gamma \mathrm{S}$ bound to membranes with an observed rate constant $\left(\mathrm{k}_{\text {obs }}\right)$ of $0.0269 \pm 0.0022 \mathrm{~min}^{-1}$. Ten $\mu \mathrm{M}$ ACh accelerated the rate of ${ }^{35}$ S]GTP $\gamma S$ binding to $0.0583 \pm 0.047 \mathrm{~min}^{-1}$ (Figure 7 , closed squares) and $1 \mu \mathrm{M}$ rapacuronium further increased the rate to $0.166 \pm 0.013 \mathrm{~min}^{-1}$ (Figure 7, open squares). While $10 \mu \mathrm{M}$ ACh alone produced only 2 -fold increase in $\left.{ }^{35} \mathrm{~S}\right] \mathrm{GTP} \gamma \mathrm{S}$ binding at $5 \mathrm{~min}$ incubation it caused nearly 5 -fold increase in the presence of $1 \mu \mathrm{M}$ rapacuronium. Estimated [35S]GTP $\gamma \mathrm{S}$ equilibrium binding $\left(B_{\text {eq }}\right)$ was the same for all 3 treatments $(10,000 \pm 300$, $10,100 \pm 100$, and $9,980 \pm 120 \mathrm{cpm}$ per well for basal, $\mathrm{ACh}$ and $\mathrm{ACh}$ with rapacuronium, respectively; mean \pm $\mathrm{SE}, \mathrm{n}=3$ ). Rapacuronium alone slightly decreased the rate of [ $\left.{ }^{35} \mathrm{~S}\right] \mathrm{GTP} \gamma \mathrm{S}$ binding (Figure 7, open circles).

Effects of rapacuronium on the association rate of highaffinity (40 nM) [ $\left.{ }^{3} \mathrm{H}\right] \mathrm{ACh}$ binding were measured after 60 min preincubation of membranes with rapacuronium. Association of $\left[{ }^{3} \mathrm{H}\right] \mathrm{ACh}$ is complex and consists of an initial very fast step in the range of seconds followed by a slower phase (Figure 8, first time point is $5 \mathrm{~s}$ ). Under control conditions (Figure 8, closed circles) the slower phase of $\left[{ }^{3} \mathrm{H}\right] \mathrm{ACh}$ association was characterized by an observed rate $\left(\mathrm{k}_{\mathrm{obs}}\right)$ in the range of $1.43\left(\mathrm{M}_{3}\right)$ to $3.5\left(\mathrm{M}_{5}\right) \mathrm{min}^{-1}$. While the presence of $1 \mu \mathrm{M}$ rapacuronium had marginal effects on $\left[{ }^{3} \mathrm{H}\right] \mathrm{ACh}$ association (Figure 8, open circles) the association binding curve became more complex and showed a peak in the presence of $10 \mu \mathrm{M}$ rapacuronium (Figure 8, hatched circles). This peak occurred at 15 to 20 seconds at odd-numbered receptors and at 30 to $50 \mathrm{sec}-$ onds at the $\mathrm{M}_{4}$ and around 90 seconds at the $\mathrm{M}_{2}$ receptor. Peak binding was higher than control binding at oddnumbered receptors, the same as control binding at $\mathrm{M}_{4}$ and lower than control binding at $\mathrm{M}_{2}$ receptor. An increase in $\left[{ }^{3} \mathrm{H}\right] \mathrm{ACh}$ binding after extended incubation (hours) occurred at $\mathrm{M}_{3}, \mathrm{M}_{4}$, and $\mathrm{M}_{5}$ receptors.

Effects of $10 \mu \mathrm{M}$ rapacuronium on the dissociation rate of high-affinity $\left[{ }^{3} \mathrm{H}\right] \mathrm{ACh}$ binding were measured after 60 min preincubation of membranes with $40 \mathrm{nM}\left[{ }^{3} \mathrm{H}\right] \mathrm{ACh}$. Dissociation was evoked by the addition of unlabeled ACh at a final concentration of $40 \mu \mathrm{M}$, either alone or mixed with $10 \mu \mathrm{M}$ rapacuronium (Figure 9, Table 6). $\left[{ }^{3} \mathrm{H}\right] \mathrm{ACh}$ dissociation curves consisted of a very rapid phase followed by a slow one, both in the absence (Figure 9, closed circles) and in the presence (Figure 9, open and hatched circles) of rapacuronium. The slower phase of $\left[{ }^{3} \mathrm{H}\right] \mathrm{ACh}$ dissociation displayed a rate $\left(\mathrm{k}_{\mathrm{off}}\right)$ in the range of $0.112\left(\mathrm{M}_{5}\right)$ to $0.507\left(\mathrm{M}_{2}\right) \mathrm{min}^{-1}$ (Figure 9, closed circles). While effects of $1 \mu \mathrm{M}$ rapacuronium on $\left[{ }^{3} \mathrm{H}\right] \mathrm{ACh}$ dissociation were marginal, $10 \mu \mathrm{M}$ rapacuronium either accelerated (odd-numbered), did not change $\left(\mathrm{M}_{4}\right)$ or slowed $\left(\mathrm{M}_{2}\right)$ the rate of $\left[{ }^{3} \mathrm{H}\right] \mathrm{ACh}$ dissociation (Figure 9 , hatched circles).

The effects of rapacuronium and the two prototypic allosteric modulators alcuronium and gallamine on ACh-stimulated [ $\left.{ }^{35} \mathrm{~S}\right] \mathrm{GTP} \gamma \mathrm{S}$ binding and kinetics of $\left[{ }^{3} \mathrm{H}\right] \mathrm{ACh}$ binding were compared at $\mathrm{M}_{3}$ receptors where the effects of rapacuronium were most pronounced. Measurements of ACh-stimulated ${ }^{35}$ S $]$ GTP $\gamma S$ binding in the presence of 1 and $10 \mu \mathrm{M}$ alcuronium or 1 and $10 \mu \mathrm{M}$ gallamine, showed a small concentration-dependent increase in the $\mathrm{EC}_{50}$ of ACh without change in $\mathrm{E}_{\mathrm{MAX}}$ values (Figure 10, Table 7). Both alcuronium and gallamine concentration dependently slowed [ ${ }^{35}$ S] GTP $\gamma \mathrm{S}$ association stimulated by $10 \mu \mathrm{M}$ ACh. At $10 \mu \mathrm{M}$ concentrations they also decreased $\left[{ }^{35}\right.$ S]GTP $\gamma \mathrm{S}$ equilibrium binding (Figure 10, Table 7). 

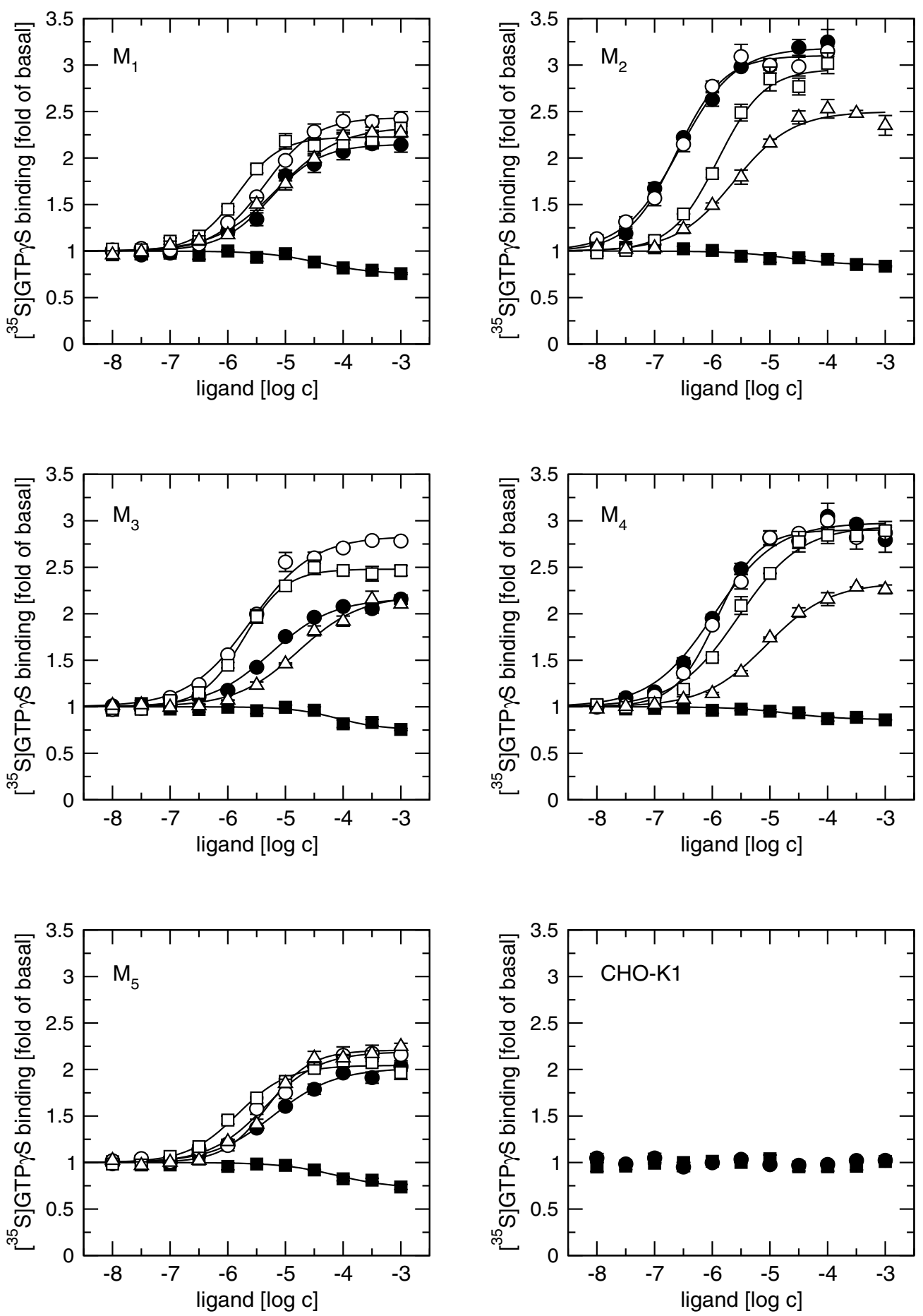

\section{Figure 6}

Effects of rapacuronium on ACh-induced [ $\left.{ }^{35} \mathbf{S}\right]$ GTP $\gamma \mathbf{S}$ binding to membranes. Membranes from $\mathrm{CHO}$ cells expressing individual subtypes of muscarinic receptors or nontransfected $\mathrm{CHO}-\mathrm{KI}$ cells were preincubated for 60 min with buffer (closed symbols) or with rapacuronium (open symbols). [ $\left.{ }^{35} \mathrm{~S}\right] \mathrm{GTP} \gamma \mathrm{S}$ binding was induced by rapacuronium alone (closed squares), $\mathrm{ACh}$ alone (closed circles), or by $\mathrm{ACh}$ in the presence of rapacuronium ( $0.1 \mu \mathrm{M}$ (open circles), I $\mu \mathrm{M}$ (open squares), or $10 \mu \mathrm{M}$ (open triangles)). Data are expressed as fold increase of basal [ $\left.{ }^{35} \mathrm{~S}\right] \mathrm{GTP} \gamma \mathrm{S}$ binding and are presented as means \pm SE from 3 independent experiments performed in quadruplicates. Curves are fits of Eq. 5 to data. Parameters are summarized in Tables 4 and 5. 
Table 5: Effects of rapacuronium on ACh-stimulated [ ${ }^{35}$ S]GTP $\gamma$ S binding

\begin{tabular}{|c|c|c|c|c|c|c|c|c|}
\hline & \multicolumn{2}{|c|}{ Acetylcholine } & \multicolumn{2}{|c|}{$+0.1 \mu M$ rapacuronium } & \multicolumn{2}{|c|}{$+I \mu M$ rapacuronium } & \multicolumn{2}{|c|}{$+10 \mu \mathrm{M}$ rapacuronium } \\
\hline & $\mathrm{pEC}_{50}$ & $E_{\text {MAX }}$ & $\mathrm{pEC}_{50}$ & $E_{\text {MAX }}$ & $\mathrm{pEC}_{50}$ & $E_{\text {MAX }}$ & $\mathrm{pEC}_{50}$ & $E_{\text {MAX }}$ \\
\hline$M_{1}$ & $5.20 \pm 0.05$ & $2.23 \pm 0.08$ & $5.41 \pm 0.04^{*}$ & $2.35 \pm 0.12$ & $5.78 \pm 0.04^{*}$ & $2.28 \pm 0.12$ & $5.22 \pm 0.05$ & $2.27 \pm 0.11$ \\
\hline$M_{2}$ & $6.61 \pm 0.03$ & $3.12 \pm 0.12$ & $6.65 \pm 0.03$ & $3.10 \pm 0.15$ & $5.92 \pm 0.05 *$ & $2.93 \pm 0.13$ & $5.67 \pm 0.07 *$ & $2.46 \pm 0.18^{*}$ \\
\hline$M_{3}$ & $5.31 \pm 0.05$ & $2.12 \pm 0.08$ & $5.65 \pm 0.04^{*}$ & $2.78 \pm 0.11 *$ & $5.66 \pm 0.04^{*}$ & $2.52 \pm 0.08^{*}$ & $4.83 \pm 0.05^{*}$ & $2.12 \pm 0.09$ \\
\hline$M_{4}$ & $5.95 \pm 0.04$ & $2.93 \pm 0.15$ & $5.93 \pm 0.04$ & $2.95 \pm 0.11$ & $5.59 \pm 0.05^{*}$ & $2.80 \pm 0.12$ & $5.12 \pm 0.05^{*}$ & $2.32 \pm 0.16^{*}$ \\
\hline$M_{5}^{4}$ & $5.26 \pm 0.05$ & $1.99 \pm 0.08$ & $5.45 \pm 0.04^{*}$ & $2.10 \pm 0.09$ & $5.82 \pm 0.04^{*}$ & $2.04 \pm 0.09$ & $5.29 \pm 0.05$ & $2.22 \pm 0.09$ \\
\hline
\end{tabular}

Negative logarithms of half effective concentrations $\left(\mathrm{PEC}_{50}\right)$ and maximum stimulatory effect $\left(\mathrm{E}_{\mathrm{MAX}}\right)$ of acetylcholine on [ $\left.{ }^{35} \mathrm{~S}\right] \mathrm{GTP} \gamma \mathrm{S}$ binding in the absence or presence of the indicated concentrations of rapacuronium were obtained by fitting Eq. 5 to the data in Figure 6 . Values are means \pm SE of fits to 3 independent experiments performed in quadruplicates. ${ }^{\mathrm{P}}<0.05$; significantly different from control (Ach alone) by ANOVA and TukeyKramer post-test.

Alcuronium and gallamine slowed down association of $40 \mathrm{nM}\left[{ }^{3} \mathrm{H}\right] \mathrm{ACh}$ and decreased its equilibrium binding at $\mathrm{M}_{3}$ receptors (Figure 10, Table 7).

\section{Discussion}

Our results clearly demonstrate that the neuromuscular blocker rapacuronium binds to all muscarinic receptor subtypes at physiologically relevant concentrations [18] and displays micromolar affinity and slight selectivity towards $\mathrm{M}_{2}$ receptor. This selectivity is smaller than that of other neuromuscular blockers such as alcuronium, gallamine and pancuronium [23, 24, Jakubík, unpublished data]. Like the majority of this class of compounds, rapacuronium acts as a negative allosteric modulator (alters dissociation kinetics and incompletely inhibits binding of orthosteric ligands) with respect to binding of both the natural agonist ACh (Figures 1, 4, 5, 8 and 9) and the classical antagonist NMS (Figures 1, 3, and 5). Rapacuronium exhibits complex effects on the kinetics of ACh binding (Figures 8 and 9) and subsequent receptor activation estimated from stimulation of [ ${ }^{35 S}$ ]GTP $\gamma \mathrm{S}$ binding (Figures 6 and 7). Functional effects differ from those of the prototypic negative allosteric modulators alcuronium and gallamine (Figure 10, Table 7).
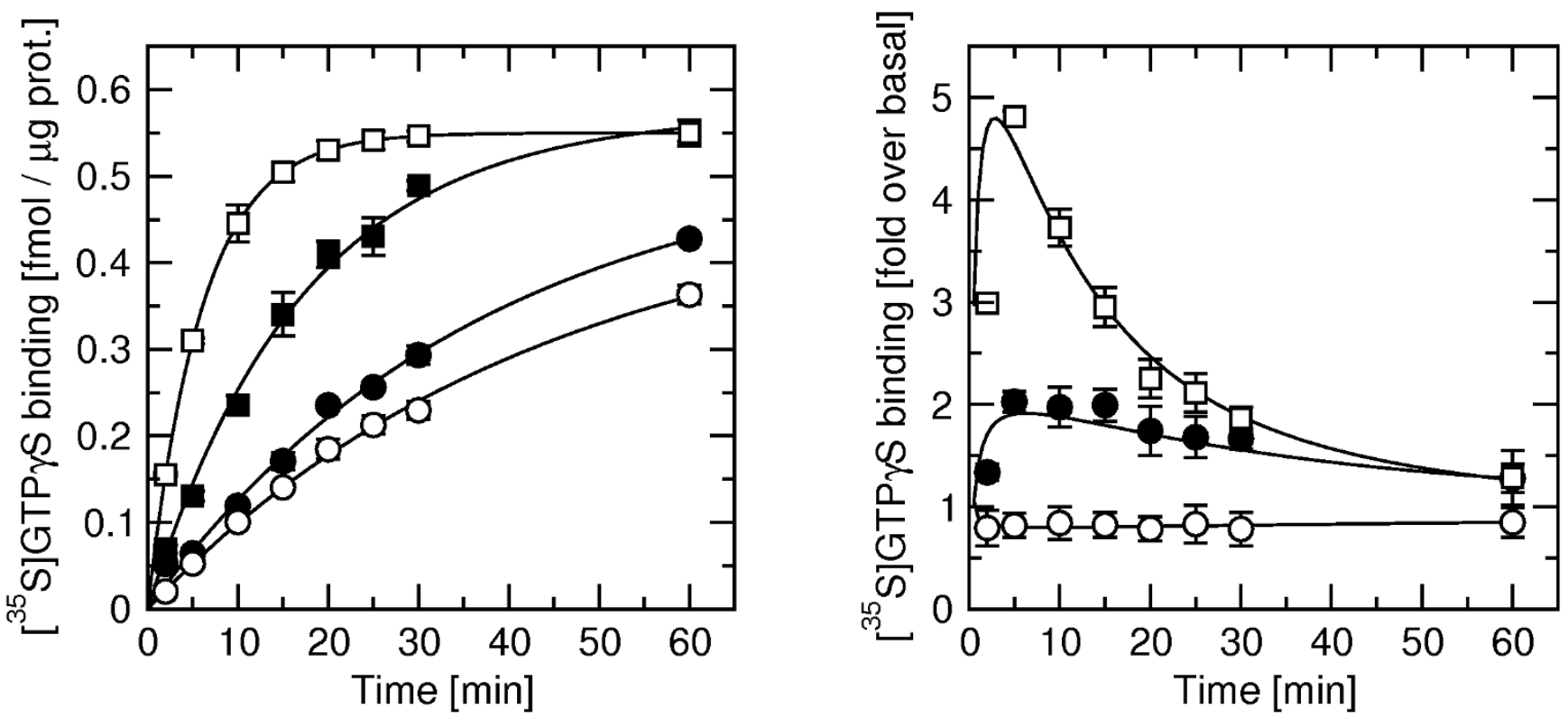

Figure 7

Effects of rapacuronium on kinetics of [ $\left.{ }^{35} \mathbf{S}\right]$ GTP $\gamma \mathbf{S}$ binding. Membranes were preincubated for $60 \mathrm{~min}$ in the presence (open symbols) or absence (closed symbols) of I $\mu \mathrm{M}$ rapacuronium. Then $\left.{ }^{35} \mathrm{~S}\right] \mathrm{GTP} \gamma \mathrm{S}$ was added simultaneously with buffer (circles) or $10 \mu \mathrm{M}$ ACh (squares). Incubations were terminated at the times indicated on the $\mathrm{x}$-axis. The increase of specific $\left[{ }^{35} \mathrm{~S}\right] \mathrm{GTP} \gamma \mathrm{S}$ binding is expressed as fmol per $\mu \mathrm{g}$ of protein (left) and as fold increase of specific binding under basal conditions (right). Data are means $\pm \mathrm{SE}$ of values from 3 independent experiments performed in quadruplicates. 

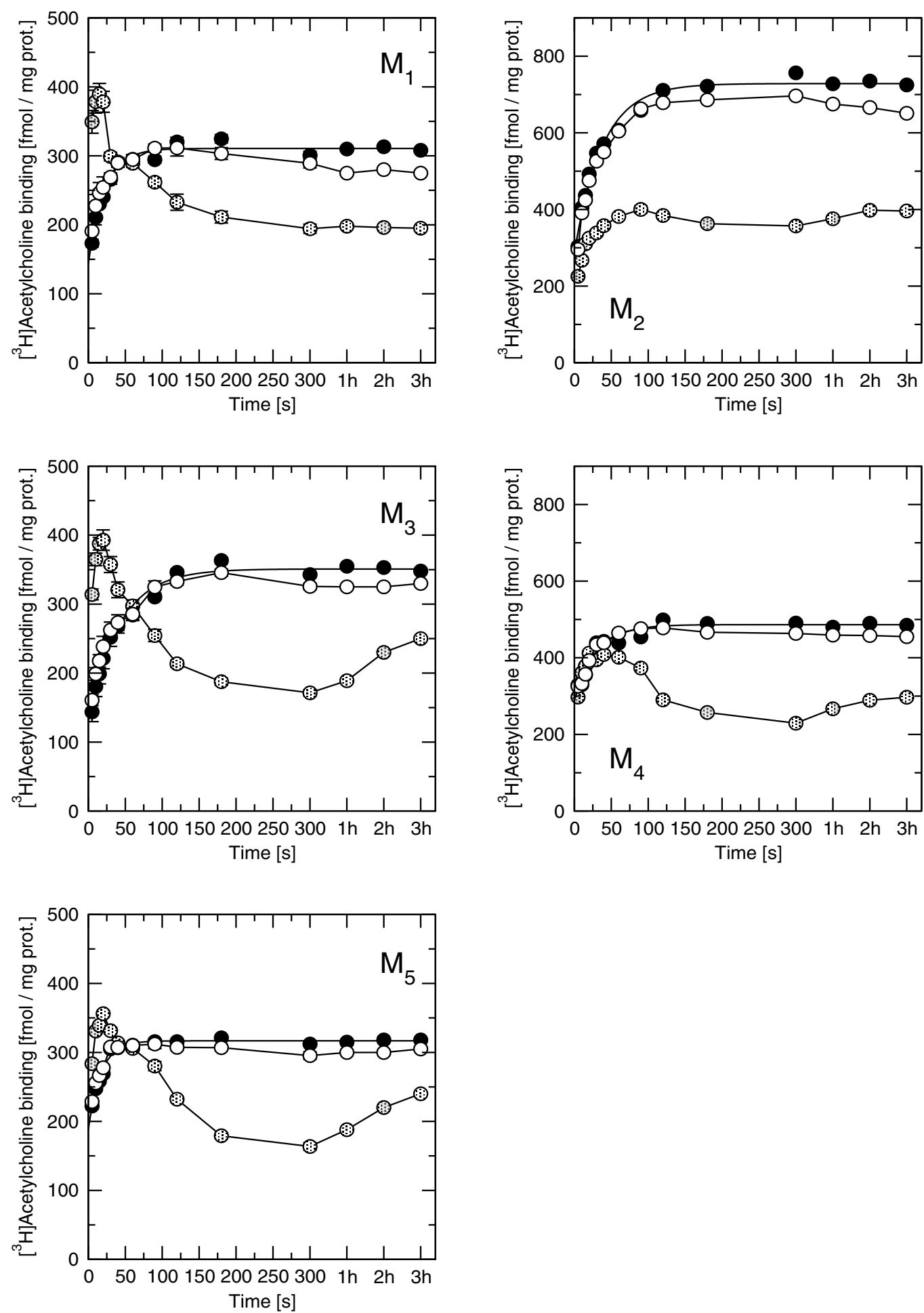

Figure 8

Effects of rapacuronium on [ $\left.{ }^{3} \mathbf{H}\right]$ ACh association. Membranes from $\mathrm{CHO}$ cells expressing individual subtypes of muscarinic receptors were preincubated $60 \mathrm{~min}$ with buffer (closed circles) or I $\mu$ M (open circles) or $10 \mu \mathrm{M}$ (hatched circles) rapacuronium and then $\left[{ }^{3} \mathrm{H}\right] \mathrm{ACh}$ was added to a final concentration of $40 \mathrm{nM}$ at time 0 . Incubations were terminated at the times indicated on the $x$-axis. Specific $\left[{ }^{3} \mathrm{H}\right] A C h$ binding is expressed as fmol per $\mathrm{mg}$ of proteins. Data are means $\pm \mathrm{SE}$ of values from 3 independent experiments performed in quadruplicates. Binding parameters are shown in Table 6. 
Table 6: Effects of rapacuronium on the rate of $\left[{ }^{3} \mathrm{H}\right] \mathrm{ACh}$ association and dissociation

\begin{tabular}{cccc}
\hline & $\begin{array}{c}\mathbf{4 0} \mathbf{~ n M}\left[{ }^{3} \mathbf{H}\right] \mathrm{ACh} \\
\mathbf{k}_{\text {obs }}\left[\mathbf{m i n}^{-1}\right]\end{array}$ & $\left.+10 \mu \mathbf{m i n}^{-1}\right]$ & $\begin{array}{c}\mu \text { rapacuronium } \\
\mathbf{k}_{\text {off }}\left[\mathbf{m i n}^{-1}\right]\end{array}$ \\
\hline$M_{1}$ & $2.74 \pm 0.25$ & $0.294 \pm 0.015$ & $0.917 \pm 0.046^{*}$ \\
$M_{2}$ & $1.58 \pm 0.14$ & $0.507 \pm 0.025$ & $0.245 \pm 0.012^{*}$ \\
$M_{3}$ & $1.43 \pm 0.13$ & $0.226 \pm 0.011$ & $0.923 \pm 0.046^{*}$ \\
$M_{4}$ & $2.01 \pm 0.18$ & $0.373 \pm 0.019$ & $0.355 \pm 0.018$ \\
$M_{5}$ & $3.50 \pm 0.31$ & $0.112 \pm 0.006$ & $0.378 \pm 0.019^{*}$
\end{tabular}

Observed rates of association ( $\left.\mathrm{k}_{\mathrm{obs}}\right)$ of $40 \mathrm{nM}\left[{ }^{3} \mathrm{H}\right] \mathrm{ACh}$ with and dissociation $\left(\mathrm{k}_{\text {off }}\right)$ from individual subtypes of muscarinic receptors were obtained by fitting Eq. 6 to data in Figure 8 and Eq. 7c to data in Figure 9. Values are means $\pm \mathrm{SE}$ of fits to 3 independent experiments performed in quadruplicates. $* \mathrm{P}<0.05$; significantly different from control $\left(\left[{ }^{3} \mathrm{H}\right] \mathrm{ACh}\right.$ alone $)$ by t-test.

Our observation of an allosteric mode of interaction between rapacuronium and muscarinic receptors is in agreement with reported slowing-down of NMS dissociation from $M_{2}$ and $M_{3}$ receptors by this drug [19]. The observed biphasic dissociation of NMS under non-equilibrium conditions in the presence of an allosteric modulator such as rapacuronium was described earlier [24].

\section{Inverse receptor agonism by rapacuronium}

Rapacuronium alone decreases [ $\left.{ }^{35} \mathrm{~S}\right] \mathrm{GTP} \gamma \mathrm{S}$ binding. This effect is mediated by muscarinic receptors because it is not observed in membranes prepared from a native $\mathrm{CHO}$ cell line that does not express muscarinic receptors and thus cannot be explained by nonspecific effects on cell membranes. Instead, this effect can be related to an inverse agonistic effect of rapacuronium itself on constitutive receptor activity. This view is supported by previous demonstration of constitutive activity of muscarinic receptors $[25,26]$ and by finding that the orthosteric antagonists NMS and atropine also decrease $\left[{ }^{35}\right.$ S]GTP $\gamma S$ binding when applied alone $[22,27]$. In addition, both agonistic and inverse agonistic effects of allosteric modulators have already been observed $[27,28]$.

\section{Allosteric modulation of receptor activation by rapacuronium}

Both $\left[{ }^{3} \mathrm{H}\right] \mathrm{ACh}$ saturation binding experiments (Figure 1) and ACh vs. $\left[{ }^{3} \mathrm{H}\right] \mathrm{NMS}$ competition experiments (Figure 2) show ACh high affinity binding in the nanomolar range without selectivity towards any of muscarinic receptor subtypes. The affinities of ACh at $\mathrm{M}_{2}$ and $\mathrm{M}_{4}$ receptors reported in this study are within the range of published values, being lower than those published by Lazareno et al. [11] but higher than the values reported by Haga et al. [29] or Gurwitz et al. [30]. This divergence is likely due to the dependence of the affinity of acetylcholine at its highaffinity site on many factors (e.g. receptor source, preparation, concentration of ions (mainly $\mathrm{Mg}^{2+}, \mathrm{Na}^{+}$), residual concentration of GDP, temperature, etc.). Similarly, we found no subtype differences in ACh low affinity binding, which is in accordance with our previous studies [21]. Despite lack of binding selectivity, the potency and efficacy of ACh in stimulating [ $\left.{ }^{35} \mathrm{~S}\right] \mathrm{GTP} \gamma \mathrm{S}$ binding are significantly higher at even-numbered than at odd-numbered subtypes. In other words, the $\mathrm{M}_{2}$ and $\mathrm{M}_{4}$ subtypes that preferentially couple with $\mathrm{G}_{\mathrm{i} / \mathrm{o}} \mathrm{G}$-proteins display better coupling and larger receptor reserve than the $M_{1}, M_{3}$, and $\mathrm{M}_{5}$ subtypes that preferentially couple with $\mathrm{G}_{\mathrm{q} / 11}$ G-proteins. Despite accumulating evidence for the existence of agonist-specific conformations of muscarinic and other G-protein-coupled receptors [31-33] it is generally accepted that the change in agonist potency in receptor activation follows a change in the affinity of its binding induced by an allosteric modulator. Thus, negative cooperativity between the allosteric modulator and the binding of an orthosteric agonist would lead to lower potency of agonist (e.g. pioneering experiments with gallamine of Clark and Mitchelson [12]) and positive cooperativity would result in higher potency of agonist $[11,34]$. Rapacuronium behaves in accordance with this view in case of the $M_{2}$ and $M_{4}$ subtypes. However, at the $M_{1}, M_{3}$ and $M_{5}$ receptor subtypes, rapacuronium up to a concentration of $10 \mu \mathrm{M}$ either increases or does not alter ACh potency or efficacy in inducing [ $\left.{ }^{35} \mathrm{~S}\right] \mathrm{GTP} \gamma \mathrm{S}$ binding (Figure 6), despite clear negative cooperativity with ACh binding (Figures 4 and 5). Although this observation may appear surprising at first glance it is perfectly in agreement with the hypothesis of multiple receptor conformations induced by orthosteric and allosteric ligands, and with the existence of conformations that exhibit low affinity for agonist binding but nevertheless activate second messenger pathways $[26,31,35,36]$.

\section{Kinetics of functional response}

Analysis of the kinetics of [ $\left.{ }^{35} S\right]$ GTP $\gamma S$ binding shows that the facilitatory effects of rapacuronium on ACh-induced responses are evident after brief incubations (lasting minutes, Figure 7). This suggests that the facilitating effects of rapacuronium on ACh-induced response are a consequence of altered receptor kinetics rather than a change in agonist affinity at equilibrium. Extended time of incubation during which binding of ligands equilibrates may thus obscure the initial transient potentiation. Analysis of kinetics of ACh binding (Figures 8 and 9) showed that rapacuronium affects ACh kinetics differently than those of NMS. While rapacuronium slows down NMS association and dissociation at all receptor subtypes (Figure 3 ) it accelerates ACh association and dissociation at odd-numbered subtypes (Figures 8 and 9). Thus, rapacuronium doubles the magnitude of ACh binding at 15 seconds at these receptors such that association after 15 seconds is twice as much in the presence of rapacuronium. This effect, however, is counterbalanced by accelerated dissociation, resulting in an overall decrease in ACh affinity (neg- 

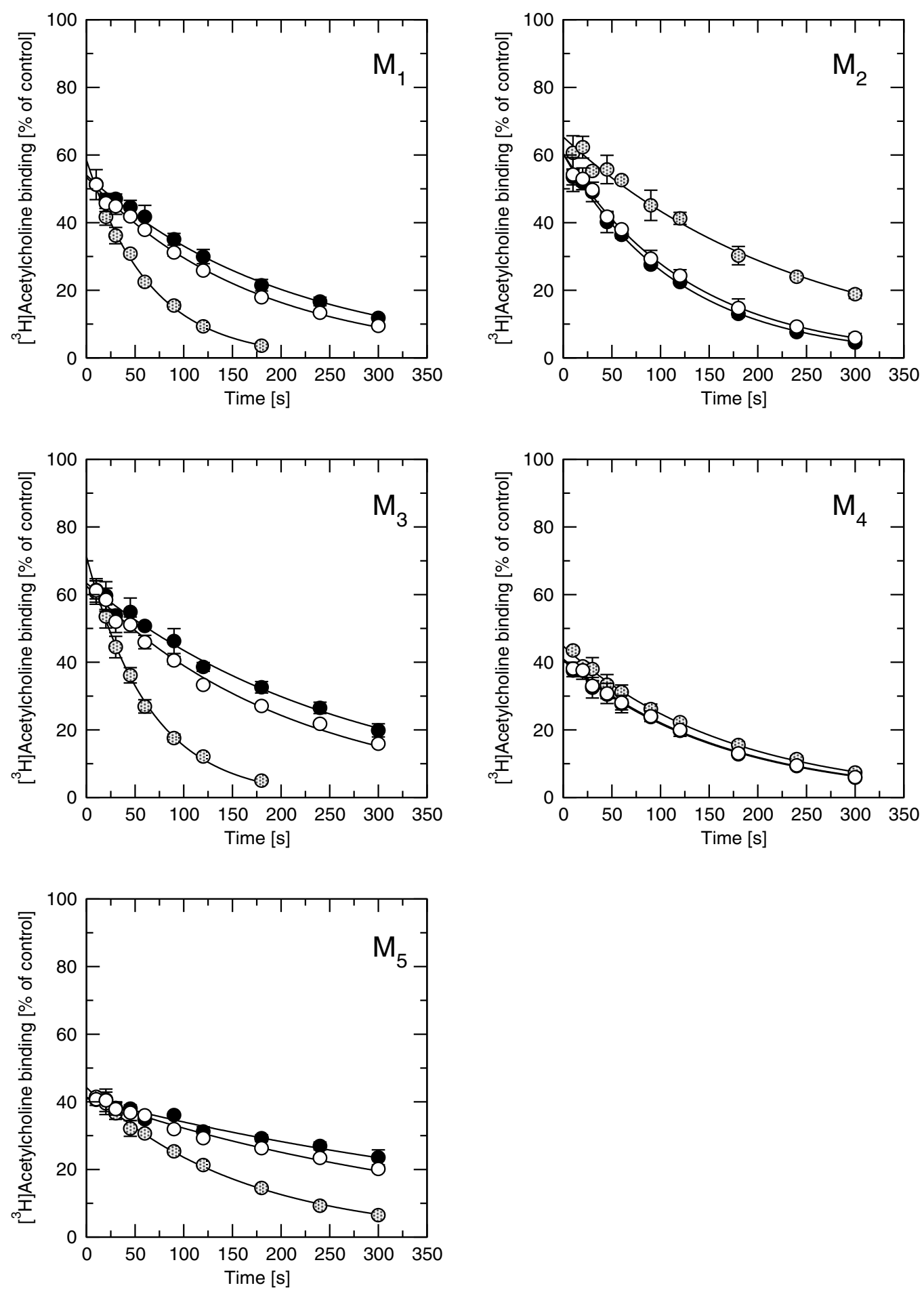

Figure 9

Effect of rapacuronium on the time course of $\left[{ }^{3} \mathrm{H}\right] \mathrm{ACh}$ dissociation. Membranes from $\mathrm{CHO}$ cells expressing individual subtypes of muscarinic receptors were prelabeled with $40 \mathrm{nM}\left[{ }^{3} \mathrm{H}\right] \mathrm{ACh}$ for $60 \mathrm{~min}$. At time zero $40 \mu \mathrm{M}$ unlabeled ACh was added alone (closed circles) or as a mixture with I $\mu \mathrm{M}$ rapacuronium (open circles) or $10 \mu \mathrm{M}$ rapacuronium (hatched circles). Incubations were terminated at the times indicated on the $x$-axis. Specific $\left[{ }^{3} \mathrm{H}\right] \mathrm{ACh}$ binding is expressed as percent of specific binding at time 0 on $x$-axis. Data are means \pm SE of values from 3 independent experiments performed in quadruplicates. Binding parameters are shown in Table 6. 
Table 7: Effects of alcuronium and gallamine on ACh-stimulated $\left[{ }^{35} \mathrm{~S}\right] \mathrm{GTP} \gamma \mathrm{S}$ binding at $\mathrm{M}_{3}$ receptors.

\begin{tabular}{|c|c|c|c|c|c|c|}
\hline & \multicolumn{3}{|c|}{$40 \mathrm{nM}\left[{ }^{3} \mathrm{H}\right] \mathrm{ACh}$ binding } & \multicolumn{3}{|l|}{ [35S]GTP $\gamma$ S binding } \\
\hline & $k_{\text {obs }}\left[\mathrm{min}^{-1}\right]$ & $B_{\text {eq }}[$ fmol/mg prot. $]$ & $\mathrm{k}_{\mathrm{obs}}\left[\mathrm{min}^{-1}\right]$ & $B_{\text {eq }}[\mathrm{fmol} / \mu \mathrm{g}$ prot. $]$ & $\mathrm{pEC}_{50}$ & $\underbrace{E_{\text {bal }}[\text { fold over }}_{\text {Max }}$ \\
\hline Control & $1.28 \pm 0.06$ & $357 \pm 17$ & $0.0579 \pm 0.0013$ & $530 \pm 37$ & $5.18 \pm 0.03$ & $2.94 \pm 0.12$ \\
\hline$+\mathrm{I} \mu \mathrm{M}$ alcuronium & $1.00 \pm 0.02 *$ & $262 \pm 10^{*}$ & $0.0509 \pm 0.0017^{*}$ & $496 \pm 33$ & $5.03 \pm 0.02 *$ & $2.90 \pm 0.14$ \\
\hline$+10 \mu \mathrm{M}$ alcuronium & $0.888 \pm 0.012^{*}$ & $199 \pm 12^{*}$ & $0.0481 \pm 0.002 I^{*}$ & $428 \pm 39 *$ & $4.82 \pm 0.02 *$ & $2.87 \pm 0.12$ \\
\hline + I $\mu \mathrm{M}$ gallamine & $1.06 \pm 0.02 *$ & $246 \pm 10 *$ & $0.0525 \pm 0.0015^{*}$ & $479 \pm 29$ & $5.01 \pm 0.04 *$ & $2.83 \pm 0.12$ \\
\hline$+10 \mu \mathrm{M}$ gallamine & $0.783 \pm 0.009 *$ & $191 \pm 8^{*}$ & $0.0492 \pm 0.0015^{*}$ & $442 \pm 27^{*}$ & $4.82 \pm 0.01^{*}$ & $2.73 \pm 0.15$ \\
\hline
\end{tabular}

Values of observed rates of association $\left(k_{\text {obs }}\right)$ and equilibrium binding $\left(B_{e q}\right)$ of $40 \mathrm{nM}\left[{ }^{3} \mathrm{H}\right] A C h$ with $M_{3}$ receptors were obtained by fitting Eq. 6 to data in Figure 10 (top). Values of $k_{\text {obs }}$ and $B_{\text {eq }}$ of 200 pM $\left.{ }^{35} \mathrm{~S}\right]$ GTP $\gamma$ S with $M_{3}$ receptors were obtained by fitting Eq. 6 to data in Figure 10 (middle). Negative logarithms of half effective concentrations $\left(\mathrm{pEC}_{50}\right)$ and maximum stimulatory effect $\left(\mathrm{E}_{\mathrm{MAX}}\right)$ of acetylcholine on $\left[{ }^{35} \mathrm{~S}\right] \mathrm{GTP} \gamma \mathrm{S}$ binding in the absence or presence of the indicated concentrations of alcuronium or gallamine were obtained by fitting Eq. 5 to the data in Figure 10 (bottom). $V$ alues are means $\pm S E$ of fits to 3 to 6 independent experiments performed in quadruplicates. *P $<0.05$; significantly different from control (ACh alone) by ANOVA and Tukey-Kramer post-test.

ative cooperativity). Although combination of negative binding cooperativity on the one hand and acceleration of binding on the other could in principle be interpreted within the frame of the ternary receptor model. However, data of association and dissociation of ACh in the absence of rapacuronium do not conform to a simple bi-molecular interaction. As a result, the interaction between ACh and rapacuronium at muscarinic receptors is more complex and may involve allosteric extension of the tandem two-site model $[37,38]$. Theoretically, this extension of the model allows for coexistence of positive cooperativity between rapacuronium and the initial step of ACh binding and overall negative binding cooperativity under equilibrium. An enigmatic feature of our data, however, is that low concentrations of rapacuronium $(0.1$ and $1 \mu \mathrm{M})$ that do not affect the the rate of binding of ACh or its affinity at equilibrium at odd numbered subtypes leads to an increase in both potency and efficacy of ACh in receptor activation. Theoreticaly, allosteric extension of tandem two-site model allows for positive cooperativity between rapacuronium and ACh initial binding step in overall negative binding cooperativity under equilibrium and transient binding of these sub-threshold concentrations. However, these concentrations of rapacuronium had no effect on ACh association in binding experiments (Figure 8 , open circles). One possible explanation is that $\mathrm{ACh}$ bound to a peripheral site (of tandem two-site binding) is lost during filtration but is well reflected and amplified in GTP $\gamma \mathrm{S}$ binding that is pseudo-irreversible. A more speculative explanation assumes that rapacuronium at submicromolar concentrations binds to another site on the receptor and facilitates receptor activation by $\mathrm{ACh}$ without significant interference with radioligand binding. This facilitatory effect is overcome at high concentrations of rapacuronium by negative cooperativity in binding of ACh induced by binding of rapacuronium to an allosteric binding site. A latent further increase in ACh binding after $5 \mathrm{~min}$ in the presence of $10 \mu \mathrm{M}$ rapacuronium (Figure 8, hatched circles) suggests an even more complex mechanism of interaction of rapacuronium wih the receptor.

Modeling of such complex kinetics would require a model even more sophisticated than ternary extension of the tandem-two site model [38]. Additionally, differential effects of low concentrations of rapacuronium $(1 \mu \mathrm{M}$ and lower $)$ on receptor binding and function would require inclusion of receptor activation (probably with several ligand-specific activation states) in the model and therefore renders modeling unachievable.

Comparison of the effects of rapacuronium with those of the prototypic allosteric modulators alcuronium and gallamine (Figures eleven and twelve) on $\mathrm{M}_{3}$ receptors shows that acceleration of ACh kinetics is unique to rapacuronium among negative allosteric modulators. To our knowledge this is the first report of acceleration of binding of an orthosteric ligand by a negative allosteric modulator. This highlights unpredictability of kinetics of allosteric modulation based on compounds with similar behavior observed under equilibrium.

\section{Physiological implications}

Our observations are consistent with functional ex vivo and in vivo physiological experiments demonstrating an increase of acetylcholine-evoked muscle contraction of guinea pig trachea rings by rapacuronium [18-20]. Although they confirm proposed allostetic interaction between rapacuronium and ACh [19] they do not conform to the proposed positive binding cooperativity at the $\mathrm{M}_{3}$ receptor subtype. Although rapacuronium at concentrations below $10 \mu \mathrm{M}$ binds to and decreases the affinity of acetylcholine at equilibrium at all subtypes of muscarinic receptors, it accelerates association of $\mathrm{ACh}$ and enhances its potency and efficacy in functional responses at the $\mathrm{M}_{3}$ receptor as evident from [ $\left.{ }^{35} \mathrm{~S}\right] \mathrm{GTP} \gamma \mathrm{S}$ binding. The initial acceleration of the rate of association of $\mathrm{ACh}$ 
alcuronium
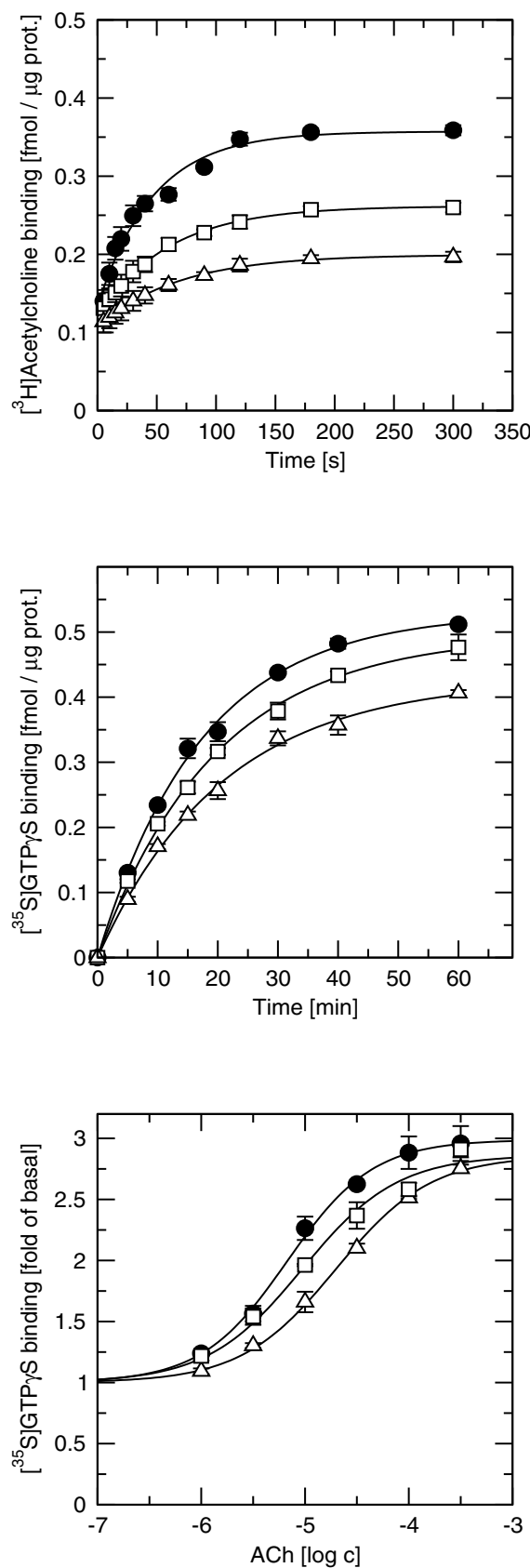

gallamine
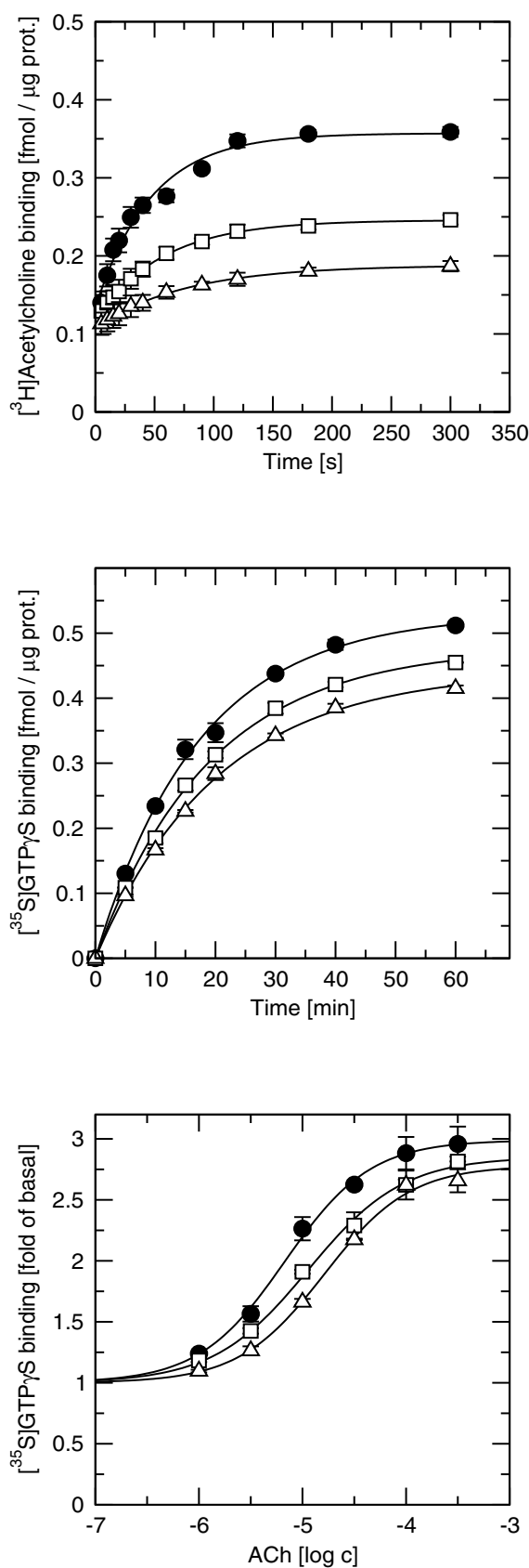

Figure 10

Effects of alcuronium and gallamine on [ $\left.{ }^{3} \mathrm{H}\right] \mathrm{ACh}$ binding and ACh-stimulated $\left[{ }^{35} \mathrm{~S}\right] \mathrm{GTP} \gamma \mathbf{S}$ binding to $\mathbf{M}_{3}$ membranes. Effects of the reference allosteric modulators alcuronium (left) and gallamine (right) on kinetics of $\left[{ }^{3} \mathrm{H}\right] \mathrm{ACh}$ binding (top) and ACh-stimulated [ $\left.{ }^{35} \mathrm{~S}\right] \mathrm{GTP} \gamma \mathrm{S}$ binding (middle) and concentration response of [ $\left.{ }^{35} \mathrm{~S}\right] \mathrm{GTP} \gamma \mathrm{S}$ binding to ACh stimulation (bottom) at $M_{3}$ receptors were measured after preincubation of membranes for 60 min with buffer (closed circles) or with I $\mu \mathrm{M}$ (open squares) or $10 \mu \mathrm{M}$ (open triangles) rapacuronium. Then either [ $\left.{ }^{3} \mathrm{H}\right] \mathrm{ACh}$ (top) or [ $\left.{ }^{35} \mathrm{~S}\right] \mathrm{GTP} \gamma \mathrm{S}$ simultaneously with I0 $\mu M$ ACh (middle and bottom) was added. Incubation was terminated at the times indicated on the $x$-axis (top and middle) or after 20 min (bottom). Binding is expressed as fmol per $\mu \mathrm{g}$ of protein of specific [ $\left.{ }^{3} \mathrm{H}\right] \mathrm{ACh}$ (top) or [ $\left.{ }^{35} \mathrm{~S}\right] \mathrm{GTP} \gamma \mathrm{S}$ (middle) binding or as fold increase of basal [ $\left.{ }^{35} \mathrm{~S}\right] \mathrm{GTP} \gamma \mathrm{S}$ binding (bottom). Data are means \pm SE from 3 to 6 independent experiments performed in quadruplicates. Parameters are summarized in Table 7. 
would potentiate fast responses such as bronchial smooth muscle contractions mediated by transient actions of acetylcholine at $\mathrm{M}_{3}$ receptors [16]. In contrast, rapacuronium at clinically relevant concentrations strongly reduces the affinity of binding of ACh and also its potency and efficacy in activating $\mathrm{M}_{2}$ receptors. This pattern of effects should lead to an increase in ACh release by interrupting its $M_{2}$ receptor-mediated presynaptic autoinhibition [17] and to the inhibition of postsynaptic $\mathrm{M}_{2}$ receptor-mediated muscle relaxation. In contrast, the decrease of ACh affinity at the $\mathrm{M}_{2}$ and $\mathrm{M}_{4}$ subtypes is accompanied by a decrease in both potency and efficacy of stimulating $\left[{ }^{35} \mathrm{~S}\right] \mathrm{GTP} \gamma \mathrm{S}$ binding. The synergistic effects of negative functional modulation of pre- and postsynaptic $\mathrm{M}_{2}$ receptors and positive functional modulation of postsynaptic $\mathrm{M}_{3}$ receptors can explain the fatal bronchospasm caused by rapacuronium in human.

\section{Conclusions}

Although rapacuronium exerts negative cooperativity with binding of ACh to all muscarinic receptor subtypes at equilibrium it accelerates the rate of ACh binding at odd numbered subtypes. At concentrations below $10 \mu \mathrm{M}$, it increases the potency and efficacy of ACh in increasing the rate of ${ }^{35}$ S]GTP $\gamma \mathrm{S}$ binding at odd-numbered subtypes. The time between acetylcholine release and termination of its action by acetylcholinesterase is in the range of a fraction of a second. Therefore, the effects of allosteric modulators in the early non-equilibrium stage of receptor signaling are therapeutically more important than effects on acetylcholine equilibrium binding, as the latter conditions do not occur in vivo. Our study demonstrates a case of dichotomous effects of the allosteric modulator rapacuronium on ACh equilibrium binding on the one hand and on the kinetics of ACh binding on the other. Our observations emphasize the necessity to employ fast functional assays in screening for potential allosteric modulators of neurotransmission that much better simulate physiological conditions than long-lasting equilibrium binding experiments.

\section{Methods \\ Materials}

The radioligands $\left[{ }^{3} \mathrm{H}\right]-\mathrm{N}$-methylscopolamine chloride $\left(\left[{ }^{3} \mathrm{H}\right] \mathrm{NMS}\right)$ and guanosine- $5^{1}-\gamma\left[{ }^{35} \mathrm{~S}\right]$ thiotrisphosphate $([35 \mathrm{~S}] \mathrm{GTP} \gamma \mathrm{S}$ ) were from Amersham (UK), [methyl$\left.{ }^{3} \mathrm{H}\right]$ acetylcholine iodide $\left(\left[{ }^{3} \mathrm{H}\right] \mathrm{ACh}\right)$ was from ARC (St. Louis, MO). Carbachol, dithiotreitol, gallamine triethiodide (TLC >98\%), guanosine-5'-bis-phosphate (GDP), guanosine-5'- $\gamma \mathrm{S}$-thiotrisphosphate (GTP $\gamma \mathrm{S}$ ), and N-methylscopolamine chloride (NMS) were from Sigma (St. Louis, MO). Rapacuronium (Organon, West Range, NJ) was kindly provided by Prof. Emala, Columbia University, New York, NY. Alcuronium was kindly provided by F. Hoffmann-la Roche Ltd., Basle, Switzerland. CHO cells stably expressing individual subtypes of muscarinic receptors were provided by Dr. T.I. Bonner (National Institutes of Health, Bethesda, MD).

\section{Cell culture and membrane preparation}

Chinese hamster ovary cells stably transfected with the human $M_{1}$ to $M_{5}$ muscarinic receptor genes were grown to confluence in $75 \mathrm{~cm}^{2}$ flasks in Dulbecco's modified Eagle's medium supplemented with $10 \%$ fetal bovine serum and 2 million cells were subcultured to $100 \mathrm{~mm}$ Petri dishes. Medium was supplemented with $5 \mathrm{mM}$ butyrate for last 24 hours of cultivation. Cells were detached by mild trypsinization on day 5 after subculture. Detached cells were washed twice in $50 \mathrm{ml}$ of phosphatebuffered saline and $3 \mathrm{~min}$ centrifugation at $250 \times \mathrm{g}$. Washed cells were diluted in ice cold homogenization medium $(100 \mathrm{mM} \mathrm{NaCl}, 20 \mathrm{mM}$ Na-HEPES, $10 \mathrm{mM}$ EDTA; $\mathrm{pH}=7.4$ ) and homogenized on ice by two $30 \mathrm{~s}$ strokes using Polytron homogenizer (Ultra-Turrax; Janke \& Kunkel GmbH \& Co. KG, IKA-Labortechnik, Staufen, Germany) with a $30 \mathrm{~s}$ pause between strokes. Cell homogenates were centrifuged for $30 \mathrm{~min}$ at $30,000 \times \mathrm{g}$. Supernatants were discarded, pellets resuspended in fresh incubation medium $(100 \mathrm{mM} \mathrm{NaCl}, 20 \mathrm{mM} \mathrm{Na}$-HEPES, $10 \mathrm{mM} \mathrm{MgCl} ; \mathrm{pH}=7.4$ ) and centrifuged again. Resulting membrane pellets were kept at $-20^{\circ} \mathrm{C}$ until assayed, for 10 weeks at maximum.

\section{Radioligand binding}

All radioligand binding experiments were carried out on membranes in 96 -well plates at $30^{\circ} \mathrm{C}$ in the incubation medium described above supplemented with freshly prepared dithiothreitol at a final concentration of $1 \mathrm{mM}$, essentially as described by Jakubík et al. [23]. Membranes at concentrations 4,50 and $100 \mu \mathrm{g}$ of protein per well were used for $\left[{ }^{35} \mathrm{~S}\right] \mathrm{GTP} \gamma \mathrm{S},\left[{ }^{3} \mathrm{H}\right] \mathrm{NMS}$ and $\left[{ }^{3} \mathrm{H}\right]$ ACh binding, respectively. Final volume was $200 \mu \mathrm{l}$, except for $\left[{ }^{3} \mathrm{H}\right] \mathrm{NMS}$ saturation binding that was done in $0.8 \mathrm{ml}$ volume. High affinity acetylcholine and NMS binding was measured directly using $\left[{ }^{3} \mathrm{H}\right] \mathrm{ACh}$ and $\left[{ }^{3} \mathrm{H}\right] \mathrm{NMS}$, respectively. Low affinity acetylcholine binding to muscarinic receptors was determined by the ability of unlabeled ACh to decrease binding of $1 \mathrm{nM}\left[{ }^{3} \mathrm{H}\right] \mathrm{NMS}$ in the presence of $10 \mu \mathrm{M}$ GTP $\gamma \mathrm{S}$. Nonspecific binding was determined in the presence of $10 \mu \mathrm{M}$ NMS. Incubation with $\left[{ }^{3} \mathrm{H}\right] \mathrm{ACh}$ or $\left.{ }^{3} \mathrm{H}\right] \mathrm{NMS}$ lasted $60 \mathrm{~min}$ and was terminated by fast filtration and washing with ice cold water through Whatman GF/F glass-fiber filters (Whatman) using a Tomtech Mach III cell harvester (Perkin Elmer, USA). Filtration and washing lasted $4 \mathrm{~s}$ for $\left[{ }^{3} \mathrm{H}\right] \mathrm{ACh}$ and $9 \mathrm{~s}$ for $\left[{ }^{3} \mathrm{H}\right] \mathrm{NMS}$ (washaspirate button times). Six concentrations of $\left[{ }^{3} \mathrm{H}\right] \mathrm{NMS}$ were used in saturation experiments $(68 \mathrm{pM}$ to $2000 \mathrm{pM}$ $\left[{ }^{3} \mathrm{H}\right] \mathrm{NMS}$ in the absence of rapacuronium and $189 \mathrm{pM}$ to $5000 \mathrm{pM}\left[{ }^{3} \mathrm{H}\right] \mathrm{NMS}$ in its presence). Corresponding concentrations of $\left[{ }^{3} \mathrm{H}\right] \mathrm{ACh}$ were $3.4 \mathrm{nM}$ to $100 \mathrm{nM}\left[{ }^{3} \mathrm{H}\right] \mathrm{ACh}$ 
in the absence of paracuronium and $7 \mathrm{nM}$ to $200 \mathrm{nM}$ $\left[{ }^{3} \mathrm{H}\right] \mathrm{ACh}$ in its presence. Effects of rapacuronium on acetylcholine high affinity binding was measured as a change in $\left[{ }^{3} \mathrm{H}\right]$ acetylcholine binding after $60 \mathrm{~min}$ prelabeling with $20 \mathrm{nM}\left[{ }^{3} \mathrm{H}\right] \mathrm{ACh}$ followed by addition of rapacuronium and incubation for additional 3 hours. Effects of rapacuronium on ACh low affinity binding was determined as a change in $\left[{ }^{3} \mathrm{H}\right] \mathrm{NMS}$ binding in the presence of $10 \mu \mathrm{M}$ GTP $\gamma \mathrm{S}$ after $60 \mathrm{~min}$ prelabeling of membranes with $1 \mathrm{nM}\left[{ }^{3} \mathrm{H}\right] \mathrm{NMS}$ followed by addition of ACh with or without rapacuronium and additional 3 hours of incubation. Effects of rapacuronium on $\left[{ }^{3} \mathrm{H}\right] \mathrm{ACh}$ association was measured after 60 min preincubation with $10 \mu \mathrm{M}$ rapacuronium. When kinetics of association were measured Bio-Tek $\mu$ Fill (Bio-Tek Instruments, Winooski, VT) was programmed for addition of hot ligand at appropriate times before filtration. Effects of rapacuronium on dissociation of $\left[{ }^{3} \mathrm{H}\right] \mathrm{NMS}$ or $\left[{ }^{3} \mathrm{H}\right]$ ACh binding was measured by addition of 10 or $100 \mu \mathrm{M}$ rapacuronium to a mixture with unlabeled ligand (10 $\mu \mathrm{M}$ NMS or $40 \mu \mathrm{M} \mathrm{ACh})$ to initiate dissociation.

For determination of [ $\left.{ }^{35} \mathrm{~S}\right] \mathrm{GTP} \gamma \mathrm{S}$ binding to G-proteins in membranes a final concentration of $200 \mathrm{pM}\left(\mathrm{M}_{1}, \mathrm{M}_{3}\right.$ and $\mathrm{M}_{5}$ receptors $)$ or $500 \mathrm{pM}\left(\mathrm{M}_{2}\right.$ and $\mathrm{M}_{4}$ receptors $)$ of $\left.{ }^{35} \mathrm{~S}\right] \mathrm{GTP} \gamma \mathrm{S}$ was used. Incubation medium was supplemented with $5 \mu \mathrm{M}\left(\mathrm{M}_{1}, \mathrm{M}_{3}\right.$ and $\mathrm{M}_{5}$ receptors $)$ or $50 \mu \mathrm{M}$ $\left(\mathrm{M}_{2}\right.$ and $\mathrm{M}_{4}$ receptors) GDP. Nonspecific binding was determined in the presence of $1 \mu \mathrm{M}$ unlabeled GTP $\gamma \mathrm{S}$. When effects of rapacuronium on ACh-stimulated $\left[{ }^{35} \mathrm{~S}\right] \mathrm{GTP} \gamma \mathrm{S}$ binding was measured rapacuronium was added to membranes $60 \mathrm{~min}$ prior to ACh and $\left[{ }^{35} \mathrm{~S}\right] \mathrm{GTP} \gamma \mathrm{S}$. Incubation with $\left.{ }^{35} \mathrm{~S}\right] \mathrm{GTP} \gamma \mathrm{S}$ was carried out for $20 \mathrm{~min}$ and free ligand was removed by filtration as described above. Filtration and washing with ice-cold water lasted for $9 \mathrm{~s}$ (wash-aspirate button time).

After filtration filters were dried in vacuum for $1 \mathrm{~h}$ while heated at $80^{\circ} \mathrm{C}$ and then solid scintillator Meltilex A was melted on filters $\left(105^{\circ} \mathrm{C}, 90 \mathrm{~s}\right)$ using a hot plate. After cooling the filters were counted using a Wallac Microbeta scintillation counter.

\section{Data analysis}

In general binding data were analyzed as described in Jakubík et al. [21]. Data were preprocessed by Open Office $3.0 \mathrm{http}: / / \mathrm{www}$.openoffice.org and subsequently analyzed by Grace $5.1 .18 \mathrm{http}: / /$ plazma-gate.weizman.ac.il/ and statistics package R http://www.r-project.org on Mandriva distribution of Linux.

The following equations were fitted to data:

Saturation of radioligand binding

$$
\mathrm{y}=\mathrm{B}_{\mathrm{MAX}} * \mathrm{x} /\left(\mathrm{x}+\mathrm{K}_{\mathrm{D}}\right)
$$

$y$, binding of radioligand $\left(\left[{ }^{3} \mathrm{H}\right] \mathrm{NMS}\right.$ or $\left[{ }^{3} \mathrm{H}\right]$ acetylcholine $)$ at free radioligand (after correction for depletion) concentration $\mathrm{x} ; \mathrm{B}_{\mathrm{MAX}}$, maximum binding capacity; $\mathrm{K}_{\mathrm{D}}$, equilibrium dissociation constant.

Competition with $\left[{ }^{3} \mathrm{H}\right] \mathrm{NMS}$ binding

$$
\mathrm{y}=100 *\left(1-\mathrm{x} /\left(\mathrm{IC}_{50}+\mathrm{x}\right)\right)
$$

$y$, binding of $\left[{ }^{3} \mathrm{H}\right] \mathrm{NMS}$ at a concentration of displacer $\mathrm{x}$ normalized to binding in the absence of displacer; $\mathrm{IC}_{50}$, concentration causing 50\% decrease in binding.

Equilibrium dissociation constant of displacer $\left(\mathrm{K}_{\mathrm{i}}\right)$ was calculated according Cheng and Prusoff [39].

Allosteric interaction between rapacuronium and $\left[{ }^{3} \mathrm{H}\right] \mathrm{NMS}$ or $\left[{ }^{3} \mathrm{H}\right]$ acetylcholine high affinity binding

$$
y=\frac{[L]+K_{D}}{[L]+\frac{K_{D} *\left(K_{A}+x\right)}{K_{A}+x / \alpha}}
$$

$y$, binding of radioligand $\left(\left[{ }^{3} \mathrm{H}\right] \mathrm{NMS}\right.$ or $\left[{ }^{3} \mathrm{H}\right]$ acetylcholine $)$ in the presence of rapacuronium at concentration $\mathrm{x}$ normalized to the absence of rapacuronium; $[\mathrm{L}]$ concentration of radioligand; $\mathrm{K}_{\mathrm{D}^{\prime}}$ equilibrium dissociation constant of radioligand; $\mathrm{K}_{\mathrm{A}}$; equilibrium dissociation constant of rapacuronium; $\alpha$, factor of cooperativity between radioligand and rapacuronium [40]. Cooperativity factor greater than 1 denotes negative cooperativity and less than 1 positive cooperativity. Due to its log-normal error distribution factors of cooperativity are expressed as negative logarithms $(p \alpha)$ through the manuscript so negative values denotes negative cooperativity and positive value denotes positive cooperativity.

Allosteric interaction between rapacuronium and acetylcholine low affinity binding

$$
y=\frac{[N]+K_{D}}{[N]+\frac{K_{D} *\left([A] *\left(K_{A}+x / \beta\right)+K_{I} *\left(K_{A}+x\right)\right)}{K_{I} *\left(K_{A}+x / \alpha\right)}}
$$

$y$, binding of $\left[{ }^{3} \mathrm{H}\right] \mathrm{NMS}$ in the presence of rapacuronium at concentration $\mathrm{x}$ normalized to the absence of rapacuronium; $[\mathrm{N}]$ concentration of $\left[{ }^{3} \mathrm{H}\right] \mathrm{NMS} ; \mathrm{K}_{\mathrm{D}^{\prime}}$ equilibrium dissociation constant of [ $\left.{ }^{3} \mathrm{H}\right] \mathrm{NMS}$; [A], concentration of acetylcholine; $\mathrm{K}_{\mathrm{I}}$, equilibrium dissociation constant form Eq. $2 ; \mathrm{K}_{\mathrm{A}} ;$ equilibrium dissociation constant of rapacuronium from Eq. 3 ; $\alpha$, factor of cooperativity between 
$\left[{ }^{3} \mathrm{H}\right] \mathrm{NMS}$ and rapacuronium from Eq. $3 ; \beta$, factor of cooperativity between rapacuronium and acetylcholine [21].

Concentration-response

$$
\mathrm{y}=1+\mathrm{E}_{\mathrm{MAX}} /\left(1+\left(\mathrm{EC}_{50}-\mathrm{x}\right)^{\mathrm{nH}}\right)
$$

$\mathrm{y}$, radioactivity in the presence of agonist at concentration $\mathrm{x}$ normalized to radioactivity in the absence of agonist; $\mathrm{E}_{\mathrm{MAX}}$, maximal increase by agonist; $\mathrm{EC}_{50}$, concentration of agonist producing $50 \%$ of maximal effect; $\mathrm{nH}$, Hill coefficient.

Time course of association

$$
y=\text { Bottom }+\operatorname{Span} *\left(1-e^{\left(-K_{o b s} * x\right)}\right)
$$

$\mathrm{y}$, radioligand binding at time $\mathrm{x} ; \mathrm{k}_{\mathrm{obs}}$, observed rate of association; equilibrium binding $\mathrm{B}_{\mathrm{eq}}=$ Bottom + Span.

Time course of dissociation

$$
y=100 * e^{\left(-k_{\text {off } 1} * x\right)}
$$

or

$$
y=\left(100-f_{2}\right) * e^{\left(-k_{\text {off } 1} * x\right)}+f_{2} * e^{\left(-k_{\text {off } 2} * x\right)}
$$

or

$$
y=f_{2} * e^{\left(-k_{o f f} * x\right)}
$$

$\mathrm{y}$, radioligand binding at time $\mathrm{x}$ normalized to binding at time $0 ; \mathrm{k}_{\mathrm{off} 1}$ and $\mathrm{k}_{\mathrm{off} 2}$, dissociation rate constants; $\mathrm{f}_{2}$, fraction of binding site with dissociation rate constant $\mathrm{k}_{\text {off2 }}$. When both Eq. 7a and 7b were fitted to data the better fit was chosen based on sum of squares F-test and runs test.

For fitting parameter estimates close to one expected were entered manually, parameters were constrained to reasonable range, the tolerance value was set to 0.01 and iteration steps to 30 . Initial values of slope factors were always 1 constrained to 0.8 to 1.2 range.

\section{List of abbreviations}

Ach: acetylcholine; ANOVA: analysis of variance; $\mathrm{CHO}$ : Chinese hamster ovary; GTP $\gamma \mathrm{S}$ : guanosine 5'-O-(3thio)triphosphate; NMS: N-methylscopolamine; TCM: ternary complex model.

\section{Authors' contributions}

JJ carried out $\left[{ }^{3} \mathrm{H}\right] \mathrm{ACh}$ and $\left[{ }^{3} \mathrm{H}\right] \mathrm{NMS}$ binding studies and performed statistical analysis. AR carried out $\left[{ }^{35}\right.$ S]GTP $\gamma \mathrm{S}$ binding studies. All authors participated in experimental design and draft manuscript. All authors read and approved final manuscript.

\section{Authors' information}

JJ is scientist, AR PhD student and VD head of Department of Neurochenistry. EEE is Professor at the University of Minnesota Medical School. JJ, VD and EEE have decades-long experience in the research of muscarinic receptors and neurochemistry.

\section{Acknowledgements}

This work was supported by Project AVOZ 50I 10509, the grants of the Grant Agency of the Czech Republic 305/09/068I, the Grant Agency of the Czech Academy of Sciences IAA500 I 10703, and the Ministry of Education, Youth and Sports, Czech Republic LC554. We thank Prof. Emala (Columbia Uni., NY) for providing us with rapacuronium.

\section{References}

I. Caulfield MP, Birdsall NJ: International union of pharmacology. XVII. classification of muscarinic acetylcholine receptors. Pharmacol Rev 1998, 50:279-290.

2. Bonner Tl: The molecular basis of muscarinic receptor diversity. Trends Neurosci 1989, I 2:|48-I5I.

3. Caulfield MP: Muscarinic receptors - characterization, coupling and function. Pharmacol Ther 1993, 58:319-379.

4. Eglen RM, Watson N: Selective muscarinic receptor agonists and antagonists. Pharmacol Toxicol 1996, 78:59-68.

5. Tuček S, Proška J: Allosteric modulation of muscarinic acetylcholine receptors. Trends Pharmacol Sci 1995, 16:205-2I2.

6. Leppik RA, Miller RC, Eck M, Paquet JL: Role of acidic amino acids in the allosteric modulation by gallamine of antagonist binding at the M2 muscarinic acetylcholine receptor. Mol Pharmacol 1994, 45:983-990.

7. Gnagey AL, Seidenberg M, Ellis J: Site-directed mutagenesis reveals two epitopes involved in the subtype selectivity of the allosteric interactions of gallamine at muscarinic acetylcholine receptors. Mol Pharmacol 1999, 56:1245- 253.

8. Krejčí A, Tuček S: Changes of cooperativity between n-methylscopolamine and allosteric modulators alcuronium and gallamine induced by mutations of external loops of muscarinic $\mathbf{m ( 3 )}$ receptors. Mol Pharmacol 200I, 60:76I-767.

9. Jakubík J, Krejčí A, Doležal V: Asparagine, valine, and threonine in the third extracellular loop of muscarinic receptor have essential roles in the positive cooperativity of strychnine-like allosteric modulators. J Pharmacol Exp Ther 2005, 3 I 3:688-696.

10. Jäger D, Schmalenbach C, Prilla S, Schrobang J, Kebig A, Sennwitz M, Heller E, Tränkle C, Holzgrabe U, Höltje H, Mohr K: Allosteric small molecules unveil a role of an extracellular e2/transmembrane helix 7 junction for $\mathbf{G}$ protein-coupled receptor activation. J Biol Chem 2007, 282:34968-34976.

II. Lazareno S, Doležal V, Popham A, Birdsall NJM: Thiochrome enhances acetylcholine affinity at muscarinic $m 4$ receptors: receptor subtype selectivity via cooperativity rather than affinity. Mol Pharmacol 2004, 65:257-266.

12. Clark AL, Mitchelson F: The inhibitory effect of gallamine on muscarinic receptors. Br J Pharmacol 1976, 58:323-33I.

13. Stockton JM, Birdsall NJ, Burgen AS, Hulme EC: Modification of the binding properties of muscarinic receptors by gallamine. Mol Pharmacol 1983, 23:55I-557.

14. Nedoma J, Dorofeeva NA, Tuček S, Shelkovnikov SA, Danilov AF: Interaction of the neuromuscular blocking drugs alcuronium, decamethonium, gallamine, pancuronium, ritebronium, tercuronium and d-tubocurarine with muscarinic acetylcholine receptors in the heart and ileum. Naunyn Schmiedebergs Arch Pharmacol 1985, 329:176-181.

15. Goudsouzian NG: Rapacuronium and bronchospasm. Anesthesiology 200I, 94:727-728.

16. Ehlert FJ: Contractile role of $\mathbf{M} 2$ and $\mathbf{M} 3$ muscarinic receptors in gastrointestinal, airway and urinary bladder smooth muscle. Life Sci 2003, 74:355-366. 
17. Coulson FR, Fryer AD: Muscarinic acetylcholine receptors and airway diseases. Pharmacol Ther 2003, 98:59-69.

18. Jooste E, Klafter F, Hirshman CA, Emala CW: A mechanism for rapacuronium-induced bronchospasm: M2 muscarinic receptor antagonism. Anesthesiology 2003, 98:906-9II.

19. Jooste EH, Sharma A, Zhang Y, Emala CW: Rapacuronium augments acetylcholine-induced bronchoconstriction via positive allosteric interactions at the M3 muscarinic receptor. Anesthesiology 2005, 103: I 195-1203.

20. Jooste E, Zhang Y, Emala CW: Neuromuscular blocking agents" differential bronchoconstrictive potential in guinea pig airways. Anesthesiology 2007, 106:763-772.

21. Jakubík J, Bačáková L, EI-Fakahany EE, Tuček S: Positive cooperativity of acetylcholine and other agonists with allosteric ligands on muscarinic acetylcholine receptors. Mol Pharmacol 1997, 52:172-179.

22. Jakubík J, El-Fakahany EE, Doležal V: Differences in kinetics of xanomeline binding and selectivity of activation of $G$ proteins at $M(1)$ and $M(2)$ muscarinic acetylcholine receptors. Mol Pharmacol 2006, 70:656-666.

23. Ellis J, Huyler J, Brann MR: Allosteric regulation of cloned $\mathbf{m} \mathbf{l -}$ m5 muscarinic receptor subtypes. Biochem Pharmacol 1991, 42:1927-1932.

24. Jakubík J, Bačáková L, el-Fakahany EE, Tuček S: Subtype selectivity of the positive allosteric action of alcuronium at cloned $\mathrm{m} \mathrm{I}$ m5 muscarinic acetylcholine receptors. J Pharmacol Exp Ther 1995, 274:1077-1083.

25. Jakubík J, Bačáková L, el-Fakahany EE, Tuček S: Constitutive activity of the $\mathrm{mI-m4}$ subtypes of muscarinic receptors in transfected cho cells and of muscarinic receptors in the heart cells revealed by negative antagonists. FEBS Lett 1995, 377:275-279.

26. Spalding TA, Burstein ES: Constitutive activity of muscarinic acetylcholine receptors. J Recept Signal Transduct Res 2006, 26:6I-85.

27. Jakubík J, Haga T, Tuček S: Effects of an agonist, allosteric modulator, and antagonist on guanosine-gamma-[35S]thiotriphosphate binding to liposomes with varying muscarinic receptor/Go protein stoichiometry. Mol Pharmacol 1998, 54:899-906

28. Jakubík J, Bačáková L, Lisá V, el-Fakahany EE, Tuček S: Activation of muscarinic acetylcholine receptors via their allosteric binding sites. Proc Natl Acad Sci USA 1996, 93:8705-8709.

29. Haga K, Haga T, Ichiyama A: Reconstitution of the muscarinic acetylcholine receptor: Guanine nucleotide-sensitive high affinity binding of agonists to purified muscarinic receptors reconstituted with GTP-binding proteins (Gi and Go). J Biol Chem 1986, 261: 10133-10140.

30. Gurwitz D, Kloog Y, Sokolovsky M: High affinity binding of [3H]acetylcholine to muscarinic receptors: Regional distribution and modulation by guanine nucleotides. Mol Pharmacol 1985, 28:297-305.

3I. Seifert R, Wenzel-Seifert K, Gether U, Kobilka BK: Functional differences between full and partial agonists: evidence for ligand-specific receptor conformations. J Pharmacol Exp Ther 2001 297: $1218-1226$.

32. Ayoub MA, Couturier C, Lucas-Meunier E, Angers S, Fossier P, Bouvier $M$, Jockers $R$ : Monitoring of ligand-independent dimerization and ligand-induced conformational changes of melatonin receptors in living cells by bioluminescence resonance energy transfer. J Biol Chem 2002, 277:21522-21528.

33. Azzi M, Charest PG, Angers S, Rousseau G, Kohout T, Bouvier M, Piñeyro G: Beta-arrestin-mediated activation of MAPK by inverse agonists reveals distinct active conformations for $\mathbf{G}$ protein-coupled receptors. Proc Natl Acad Sci USA 2003, 100:I|406-I|4|I.

34. Birdsall NJ, Farries T, Gharagozloo P, Kobayashi S, Lazareno S, Sugimoto $M$ : Subtype-selective positive cooperative interactions between brucine analogs and acetylcholine at muscarinic receptors: Functional studies. Mol Pharmacol 1999, 55:778-786.

35. Langmead C], Christopoulos A: Allosteric agonists of 7TM receptors: expanding the pharmacological toolbox. Trends Pharmacol Sci 2006, 27:475-481.

36. Schwartz TW, Holst B: Ago-allosteric modulation and other types of allostery in dimeric 7TM receptors. J Recept Signal Transduct Res 2006, 26:107-128.
37. Jakubík J, El-Fakahany EE, Tuček S: Evidence for a tandem twosite model of ligand binding to muscarinic acetylcholine receptors. J Biol Chem 2000, 275: | 8836-18844.

38. Ehlert FJ, Griffin MT: Two-state models and the analysis of the allosteric effect of gallamine at the M2 muscarinic receptor. J Pharmacol Exp Ther 2008, 325:1039-1060.

39. Cheng Y, Prusoff WH: Relationship between the inhibition constant $(k \mathrm{l})$ and the concentration of inhibitor which causes 50 per cent inhibition (i50) of an enzymatic reaction. Biochem Pharmacol 1973, 22:3099-3108.

40. Ehlert FJ: Estimation of the affinities of allosteric ligands using radioligand binding and pharmacological null methods. Mol Pharmacol 1988, 33:187-194.
Publish with Bio Med Central and every scientist can read your work free of charge

"BioMed Central will be the most significant development for disseminating the results of biomedical research in our lifetime. "

Sir Paul Nurse, Cancer Research UK

Your research papers will be:

- available free of charge to the entire biomedical community

- peer reviewed and published immediately upon acceptance

- cited in PubMed and archived on PubMed Central

- yours - you keep the copyright
BiolMedcentral 